\title{
Osteoartrite experimental em ratos: efeito de sulfato de glicosamina e sulfato de condroitina sobre a incapacitação articular e a lesão da cartilagem articular
}

\author{
Tese apresentada à Faculdade de Medicina da \\ Universidade de São Paulo para obtenção do título \\ de Doutor em Ciências \\ Área de concentração: Reumatologia \\ Orientador: Prof. Dr. Natalino Hajime Yoshinari \\ Co-orientador: Prof. Dr. Francisco Airton Castro da \\ Rocha
}

São Paulo

2007 


\section{Dados Internacionais de Catalogação na Publicação (CIP)}

Preparada pela Biblioteca da

Faculdade de Medicina da Universidade de São Paulo

Oreprodução autorizada pelo autor

Silva Junior, Francisco Saraiva da

Osteoartrite experimental em ratos : efeito de sulfato de glicosamina e sulfato de condroitina sobre a incapacitação articular e a lesão da cartilagem / Francisco Saraiva da Silva Junior. -- São Paulo, 2007.

Tese(doutorado)—Faculdade de Medicina da Universidade de São Paulo. Departamento de Clínica Médica.

Área de concentração: Reumatologia.

Orientador: Natalino Hajime Yoshinari.

Co-orientador: Francisco Airton Castro da Rocha.

Descritores: 1.Osteoartrite 2.Sulfatos de condroitina 3.Artralgia 4.Medição da dor 5.Ligamento cruzado anterior 6.Glicosaminoglicanas 7.Glucosamina 8.Modelos animais 9.Ratos

USP/FM/SBD-011/07 


\section{DEDICATÓRIA}

A Deus, por me dar forças sempre,

Aos meus amados pais, Saraiva e Nilza, exemplos de caráter e fortaleza,

Aos meus anjos, Pedro Gabriel e Rafael, por seu amor e alegria, papai tem orgulho de vocês,

A minha amada Barbara, por seu amor, compreensão e apoio constantes,

Aos meus irmãos, Sandra e Júlio César, companheiros de todas as caminhadas. 


\section{AGRADECIMENTOS}

Ao Prof. Dr. Natalino Hajime Yoshinari, por sua orientação mesmo a distância, e em particular por sua paciência e compreensão com os percalços durante o desenrolar dessa tese.

Ao Prof. Dr. Francisco Airton Castro da Rocha, por sua orientação nesse trabalho, mas em especial por sua amizade e por ter me acolhido em seu consultório, em sua casa e em sua vida, e por todas as portas que tem me ajudado a abrir.

A Prof. Dra. Eloísa Bonfá, por ter permitido que esse trabalho fosse desenvolvido em Fortaleza.

Ao amigo Rondinelle Ribeiro Castro, por sua amizade e inestimável ajuda em todas as etapas desse trabalho.

A Dra. Margarida e a Dra. Virgínia, por terem avaliado as lâminas histológicas. 
Aos alunos de iniciação científica, Marcus Paulo, Bruno, Glória, Patrícia, André, Isabelle e Marcela, por terem dividido a pesada tarefa da realização dos experimentos e cuidado dos animais, em particular pelos fins de semana, feriados e intervalos de almoço dedicados a este trabalho.

Aos colegas do LIO, Carol, Karine, Virgínia, pela convivência, amizade e ajuda.

Ao meu cunhado João Luis Falcão, por sempre ter me recebido tão bem em sua casa, por ser a boa pessoa que é, e exemplo de profissional.

Ao amigo Susumo, amizade e apoio sempre disponíveis nas vindas a São Paulo.

Aos colegas do serviço de Reumatologia do Hospital Universitário Walter Cantídio, por sua amizade e compreensão com as ausências necessárias para que esse trabalho pudesse ser realizado.

A secretaria do Serviço de Reumatologia da USP, em particular a Fátima, por sua presteza, simpatia e auxílio indispensáveis. 


\section{Sumário}

página

Resumo

Summary

Introdução 1

Considerações gerais 1

Osteoartrite e inflamação $\quad 5$

Osteoartrite e dor $\quad 8$

$\begin{array}{ll}\text { Cartilagem articular } & 14\end{array}$

Sulfato de glicosamina e sulfato de condroitina 20

Transecção do ligamento cruzado anterior em ratos 25

Objetivos 30

$\begin{array}{ll}\text { Materiais e Métodos } & 31\end{array}$

Animais 31

$\begin{array}{ll}\text { Drogas } & 31\end{array}$

Transecção do ligamento cruzado anterior 32

Avaliação da incapacitação articular (dor articular) 32

Tratamentos $\quad 35$

Coleta do líquido sinovial e das extremidades femorais 35

$\begin{array}{ll}\text { Extração dos GAGs da cartilagem articular } & 37\end{array}$

Quantificação dos GAGs da cartilagem articular por eletroforese em $\quad 38$ gel de agarose

Avaliação do peso molecular das cadeias de CS extraídas da 38 cartilagem articular por eletroforese em gel de poliacrilamida
Avaliação histopatológica 3

Quantificação do NO no lavado articular $\quad 40$

Estatística $\quad 41$ 
$\begin{array}{ll}\text { Resultados } & 42\end{array}$

Efeito de Sulfato de Glicosamina e Sulfato de Glicosamina / Sulfato de 42 Condroitina sobre a incapacitação articular

Caracterização dos GAGs da cartilagem articular $\quad 45$

Quantificação dos GAGs após eletroforese em gel de agarose 45

Avaliação do peso molecular dos GAGs por eletroforese em gel de $\quad 46$ poliacrilamida

Efeito de Glu e GluChon sobre a lesão da cartilagem articular $\quad 47$

Efeito de Glu e GluChon sobre os GAGs da cartilagem articular $\quad 47$

Efeito de Glu e GluChon sobre a lesão histopatológica 50

Efeito de Glu e GluChon sobre a liberação de NO na cavidade 54 articular

Discussão

$\begin{array}{ll}\text { Conclusões } & 65\end{array}$

$\begin{array}{ll}\text { Referências } & 67\end{array}$ 


\section{RESUMO}

Silva Jr FS. Osteoartrite experimental em ratos: efeito de sulfato de glicosamina e sulfato de condroitina sobre a incapacitação articular e a lesão da cartilagem [tese]. São Paulo: Faculdade de Medicina, Universidade de São Paulo; 2007. 84p.

OBJETIVOS: Avaliar o efeito de sulfato de glicosamina e sulfato de condroitina sobre a nocicepção e o dano da cartilagem articular em um modelo de osteoartrite experimental em ratos. MÉTODOS: Osteoartrite (OA) foi induzida em ratos Wistar machos por transecção do ligamento cruzado anterior (TLCA) do joelho direito. Um grupo falso-operado (SHAM) foi utilizado como controle. Animais OA foram tratados v.o. desde 7 dias antes, até o sacrifício, 70 dias após a TLCA, com sulfato de glicosamina $500 \mathrm{mg} / \mathrm{kg}$ (Glu), a combinação sulfato de glicosamina $500 \mathrm{mg} / \mathrm{kg}$ e sulfato de condroitina $400 \mathrm{mg} / \mathrm{kg}$ (GluChon), ou salina (OANT). Um grupo controle positivo recebeu meloxicam $6 \mathrm{mg} / \mathrm{kg}$ s.c. A dor articular foi avaliada pelo teste de incapacitação articular para ratos. Os animais foram sacrificados em diferentes períodos (7,14,28 e 70 dias) após a TLCA. A gravidade das lesões histopatológicas foi graduada nos fêmures após coloração por H\&E e azul de toluidina através do escore da OARSI. A quantidade de glicosaminoglicanos (GAGs) extraídos da cartilagem articular dos côndilos femorais foi medida após eletroforese em gel de agarose. O tamanho molecular dos GAGs foi medido após eletroforese em gel de poliacrilamida. A liberação de NO no líquido sinovial foi medida 7 dias após TLCA. RESULTADOS: GluChon reduziu significativamente a dor articular nesse modelo $(p<0,01)$. Glu também reduziu a dor articular, mas não se alcançou significância estatística. Os animais OA apresentaram um aumento significativo dos GAGs na cartilagem articular aos 70 dias após TLCA $(77,68 \pm 3,38 \mu \mathrm{g} / \mathrm{mg})$ quando comparados aos animais SHAM $(53,46 \pm 4,58 \mu \mathrm{g} / \mathrm{mg})$. O tamanho molecular dos GAGs foi significativamente maior nos animais $O A$ que nos animais SHAM 70 dias após a cirurgia $(p<0,01)$. GluChon preveniu tanto o aumento da quantidade de GAGs $(54,42 \pm 5,39 \mu \mathrm{g} / \mathrm{mg})$, quanto de seu tamanho molecular $(p<0,05)$, e estes resultados acompanharam-se de melhora significativa da lesão histopatológica $(p<0,05)$. Os resultados obtidos com Glu foram semelhantes, porém menos evidentes, e não alcançaram significância estatística. Glu aumentou significativamente a quantidade de NO na cavidade articular 7 dias após a TLCA. CONCLUSÕES: GluChon foi antinociceptivo e reduziu significativamente a incapacitação articular. A lesão da cartilagem articular no modelo de TLCA em ratos se acompanha de aumento da concentração e do tamanho molecular dos GAGs, e o tratamento com GluChon previne essas alterações e reduz o dano histopatológico. GluChon foi mais eficaz do que Glu tanto na redução da dor quanto da lesão da cartilagem articular, sugerindo benefício da combinação sobre o uso isolado de sulfato de glicosamina. 


\section{SUMMARY}

Silva Jr FS. Experimental osteoarthritis in rats: evaluation of antinociceptive and chondroprotective effects of glucosamine sulfate and chondroitin sulfate [thesis]. São Paulo: "Faculdade de Medicina, Universidade de São Paulo"; 2007. 84p.

OBJECTIVES: Evaluate the antinociceptive and chondroprotective effects of glucosamine sulfate and chondroitin sulfate. METHODS: Male Wistar rats underwent anterior cruciate ligament transection (ACLT) or sham operation of the right knee. Animals were treated p.o. with glucosamine sulfate (Glu) $500 \mathrm{mg} / \mathrm{kg}$, the combination of glucosamine sulfate $500 \mathrm{mg} / \mathrm{kg}$ and chondroitin sulfate $400 \mathrm{mg} / \mathrm{kg}$ (GluChon), or saline, since 7 days prior to surgery until the sacrifice 70 days after ACLT. A positive control group received meloxicam $6 \mathrm{mg} / \mathrm{kg}$ s.c. for antinociceptive evaluation comparisons. Joint pain was evaluated with rat incapacitation test. Animals were sacrificed $7,14,28$ or 70 days after ACLT. The severity of histopathologic lesions was evaluated on femoral condyles after hematoxylin-eosin or toluidine blue staining with OARSI grading and staging system. Cartilage extracted glycosaminoglycans (GAGs) concentration was assessed after agarose gel electrophoresis. GAGs' molecular weight was evaluated after polyacrylamide gel electrophoresis. NO release in synovial fluids was assessed 7 days after ACLT. RESULTS: GluChon reduced joint pain $(p<0.01)$. Glu also reduced joint pain, but results did not reach statistical significance. A significant increase in articular cartilage's GAGs concentration was observed in $\mathrm{OA}$ animals $(77.68 \pm 3.38 \mu \mathrm{g} / \mathrm{mg})$ as compared to sham $(53.46 \pm 4.58 \mu \mathrm{g} / \mathrm{mg})$. OA animals also had significantly higher molecular weight GAGs than sham $(p<0.01)$. GluChon prevented both GAG concentration and molecular weight elevations in $O A$ animals, and that was associated with significant less cartilage damage assessed by histopathologic examination $(p<0.05)$. Glu effects were less evident, and did not reach statistical significance. Glu was associated with significant higher concentrations of $\mathrm{NO}$ in synovial fluid. CONCLUSIONS: GluChon was antinociceptive on the ACLT model in rats. Articular cartilage damage was associated with increased amounts of GAG with higher molecular weight, and the prevention of these alterations with GluChon treatment was associated with less histopathologic damage. GluChon was more efficient than Glu for both pain and articular cartilage damage reduction, suggesting that combined treatment is better than glucosamine sulfate alone.

Descriptors: 1.osteoarthritis 2.chondroitin sulfate 3.joint pain 4.pain evaluation 5.anterior cruciate ligament 6.glycosaminoglycans 7.glucosamine 8.animal models 9.rats 


\section{INTRODUÇÃO}

\section{Considerações gerais}

Embora anteriormente tida como uma patologia degenerativa própria do envelhecimento, por uso e desgaste da articulação, a osteoartrose vem sendo considerada mais recentemente como uma doença inflamatória e de intensa atividade metabólica, e o termo osteoartrite $(\mathrm{OA})$ é considerado mais adequado $^{1}$. A OA resulta tanto de eventos mecânicos quanto biológicos que desequilibram o acoplamento normal entre a degradação e a síntese das células na matriz extracelular da cartilagem e do osso subcondral. A doença pode ser iniciada por múltiplos fatores, incluindo fatores genéticos, metabólicos e traumáticos, levando a alterações morfológicas, bioquímicas, moleculares e biomecânicas tanto das células quanto da matriz extracelular, as quais resultam em fibrilação, ulceração e perda da cartilagem articular, e remodelação e esclerose do osso subcondral, com formação de osteófitos ${ }^{2}$.

Sinovite leve e persistente, fibrose da cápsula articular, frouxidão ligamentar e atrofia da musculatura periarticular também fazem parte do quadro da OA, que pode ser considerada como um estado de insuficiência de toda a articulação diartrodial. Quando clinicamente manifesta, caracteriza-se por dor articular, limitação de movimentos, crepitações, deformidades, e ocasionalmente derrame articular, sem manifestações sistêmicas. Apesar de poder afetar qualquer articulação sinovial, acomete 
mais frequentemente joelhos, quadris, mãos e coluna, podendo ocorrer em uma única articulação, mas habitualmente é poliarticular.

A OA apresenta alta prevalência, sendo considerada a doença osteoarticular mais comum. É uma das principais causas de morbidade na população idosa, e está associada a elevado custo social. A OMS estima que $40 \%$ dos adultos acima de 70 anos apresentem OA de joelhos, $80 \%$ das pessoas com OA apresentem limitação de movimentos, e $25 \%$ não consigam desempenhar suas principais atividades de vida diária ${ }^{3}$. Nos Estados Unidos, a OA é a segunda maior causa de incapacidade ocupacional em homens acima de 50 anos, superada apenas pela doença coronariana $^{4}$. No Brasil, a OA respondeu por $18,6 \%$ dos 1.398 .266 benefícios concedidos pelo Instituto Nacional do Seguro Social (INSS) de janeiro a outubro de $2005^{5}$. Sua prevalência e impacto como problema de saúde pública tendem a aumentar com o envelhecimento da população, e a OA é uma doenças em foco na Década do Osso e da Articulação ${ }^{6}$.

Tradicionalmente considerada uma doença lentamente progressiva, a história natural da OA não está completamente definida, e sua evolução é variável. Em geral, uma vez sintomático, o paciente passa a apresentar dor recorrente ou constante pelo resto de sua vida, e a incapacidade funcional tende a piorar lentamente ao longo dos anos. Contudo, sua evolução é heterogênea, e enquanto boa parte dos pacientes realmente piora da dor e função, muitos permanecem com a sintomatologia estável ou mesmo melhoram $^{7,8}$. A piora sintomática envolve diversos fatores, e a progressão do dano estrutural nem sempre se acompanha de piora clínica. Em mulheres 
acima de 65 anos com OA de quadril radiográfica, por exemplo, 64,6\% das articulações avaliadas apresentaram piora radiológica, 22,8\% das pacientes apresentaram piora funcional, e $12,9 \%$ das pacientes evoluíram para colocação de prótese de quadril ${ }^{9}$. Fatores psicossociais, como nível educacional, depressão, ansiedade, capacidade de lidar com a doença, além da presença de outros comorbidades, estão associados à piora sintomática ${ }^{10}$. A OA é portanto uma doença multifatorial e complexa, de difícil caracterização, o que tem dificultado o desenvolvimento de modelos experimentais que expressem todos os aspectos da doença humana.

O tratamento clínico da OA permanece paliativo e pouco eficaz ${ }^{12,13,14}$. Nenhuma terapêutica produz o benefício sintomático da prótese articular de joelho ou quadril ${ }^{12}$. Essa realidade representa um desafio para a pesquisa médica, em particular para a Reumatologia. Considerável esforço tem sido empreendido pela comunidade acadêmica e pela indústria farmacêutica para compreender e explorar as diversas vias etiopatogênicas envolvidas na iniciação e progressão da doença no sentido de desenvolver drogas capazes de modificar sua evolução natural, as chamadas Drogas Modificadoras da Osteoartrite (DMOAs). Compostos capazes de bloquear a ação de enzimas degradadoras da matriz extracelular e de citocinas inflamatórias, e de alterar o metabolismo ósseo, têm sido testados em animais e em estudos clínicos. Implícito no conceito de modificar a evolução da lesão estrutural estaria a idéia de que isto melhoraria os sintomas e qualidade de vida, o que porém não está completamente estabelecido ${ }^{15}$. 
Dentre os candidatos a DMOA, sulfato de glicosamina e sulfato de condroitina encontram-se no cerne de intenso debate na literatura. Apesar de existirem evidências em estudos clínicos bem desenhados de que tanto sulfato de glicosamina ${ }^{16,17}$, quanto sulfato de condroitina ${ }^{18}$ reduzem a perda do espaço articular radiográfico em pacientes com OA de joelhos, críticas com relação a padronização utilizada na obtenção das radiografias e estudos posteriores que não confirmaram melhora sintomática tem posto em cheque o benefício desses compostos ${ }^{20}$.

Modelos experimentais de OA podem ser utilizados para compreensão de aspectos fisiopatológicos, bem como para avaliação da eficácia de DMOAs. Apesar de vários modelos apresentarem características histopatológicas compatíveis com as alterações no homem, um dos hiatos na pesquisa em OA até recentemente era a ausência de modelos animais que avaliassem a dor associada à $O A$. O modelo de transecção do ligamento cruzado anterior (TLCA) em ratos apresenta alterações na cartilagem articular compatíveis com a OA humana ${ }^{21}$. Nosso grupo padronizou recentemente um método reprodutível para avaliação de dor articular no modelo de TLCA em ratos ${ }^{22}$. Temos trabalhado também com a avaliação da lesão da cartilagem articular em modelos experimentais através da quantificação de glicosaminoglicanos na cartilagem ${ }^{23,24}$. Nenhum estudo até o momento avaliou o efeito analgésico de sulfato de glicosamina e sulfato de condroitina na OA experimental. Propusemos assim a estudar o efeito de sulfato de glicosamina e de sua combinação com sulfato de 
condroitina, sobre a incapacitação articular e a lesão da cartilagem articular no modelo de OA por TLCA em ratos.

\section{Osteoartrite e Inflamação}

Classicamente considerada como uma artropatia não inflamatória, a inflamação é hoje considerada central na fisiopatologia da $O A^{1}$. O caráter multifatorial da etiopatogenia da doença já foi enfatizado, onde estresse mecânico em associação a alterações inflamatórias, agindo em um indivíduo geneticamente susceptível, levam a um estado de insuficiência da articulação diartrodial. A caracterização de uma pletora de mediadores inflamatórios, tais como citocinas, produtos da ciclooxigenase e da lipooxigenase, óxido nítrico, espécies reativas de oxigênio, fatores de crescimento, metaloproteinases da matriz, dentro outros, oferece a perspectiva de desenvolvimento de intervenções farmacológicas específicas capazes de bloquear a evolução natural da doença ${ }^{25}$.

Algum grau de sinovite está presente desde as fases iniciais da OA. Acredita-se que essa sinovite seja secundária a liberação de fragmentos da matriz extracelular da cartilagem no líquido sinovial, e que a inflamação da sinóvia, com a produção de mediadores inflamatórios, leve a mais degradação da cartilagem, resultando em um ciclo vicioso. A sinovite na OA se caracteriza por hipertrofia e hiperplasia, angiogênese, e infiltração por células inflamatórias que incluem macrófagos, linfócitos $B$ e linfócitos $T^{26}$. 
Em situações inflamatórias, a presença de linfócitos e macrófagos constitui importante fonte de citocinas. Além dos sinoviócitos $A$ e $B$, que se assemelham a macrófagos e fibroblastos, respectivamente, tendo capacidade de produzir citocinas, o condrócito também está implicado na sua produção'. Tem-se então que, no ambiente articular inflamado, existe uma população residente e de células migradas capazes de iniciar e perpetuar a lesão tecidual. De fato, demonstrou-se expressão de IL-1 $\alpha$ e IL$1 \beta$ em condrócitos e na matriz da cartilagem, sendo mais intensa em espécimes de cartilagem artrósica. In vitro, as ações da IL-1 levam à lise da cartilagem, por ativação da síntese de metaloproteinases da matriz (MMP) e redução da síntese dos fatores tissulares de inibição das metaloproteinases (TIMP), além de inibição direta da síntese de colágeno e de proteoglicanos. O TNF- $\alpha$ age em sinergismo com a IL-1, além de promoverem liberação de prostaglandina E2 e de IL-6. Esta última potencia os efeitos da IL-1. Quanto à PGE2, além de promover aumento de permeabilidade vascular e vasodilatação, estimula reabsorção óssea e aumenta a expressão do receptor de IL-1. Em contraposição, o TGF- $\beta$ e o IGF-1 antagonizam esses efeitos por induzirem aumento da síntese de proteoglicanos, o TGF- $\beta$ aumentando diretamente a produção de TIMP tanto a nível de tradução como de síntese proteica. In vivo, a administração de IL-1 promove degradação da cartilagem articular, efeito esse que é potenciado na presença de TNF- $\alpha$. A ação conjunta das citocinas é mais importante do que o seu efeito isolado $25,27,28$. 
No modelo de transecção do ligamento cruzado anterior do joelho de cães, demonstrou-se que o tratamento com um antagonista do receptor de IL-1 (IL-1RA) protegeu para o surgimento de lesões artrósicas, possivelmente por supressão de atividade da colagenase ${ }^{29}$. Esse tipo de estratégia terapêutica começa a ser visualizado, e de fato já se avaliou a segurança da injeção intraarticular de IL-1RA recombinante humano em pacientes com $O A$ de joelhos ${ }^{30}$, primeiro passo na direção de um estudo clínico. O bloqueio do TNF- $\alpha$ também tem sido aventado ${ }^{31}$, e o uso de inibidores de citocinas, análogo ao que tem sido aplicado ao tratamento da artrite reumatóide, pode oferecer uma terapêutica alvo-específica em um futuro próximo.

Além dos prostanóides, os leucotrienos, particularmente o leucotrieno $\mathrm{B}_{4}$ (LTB4), têm sido associados à lesão articular em osteoartrose experimental $^{32}$. Além de ativar neutrófilos e macrófagos, promovendo "burst" oxidativo e conseqüente produção de espécies reativas de oxigênio, o LTB 4 é capaz de estimular a produção de citocinas tais como IL-1, IL-6 e IL-8 ${ }^{32}$. In vitro, demostrou-se que o LTB4 estimulou a produção de IL1- $\beta$ e TNF- $\alpha$ pela sinóvia de pacientes com OA, e que a adição de um inibidor de lipoxigenase inibiu esse efeito ${ }^{33}$. Em recente revisão do assunto, admite-se que bloqueadores duais de ciclo e lipoxigenase podem ter mais eficácia em osteoartrite quando comparados a inibidores apenas de cicloxigenase ${ }^{32}$. De fato, o licofelone, uma droga com essas características, reduziu a progressão da lesão estrutural no modelo de ressecção do ligamento cruzado anterior em cães ${ }^{34}$. 
O óxido nítrico (NO) está envolvido no catabolismo da cartilagem articular na OA. A cartilagem artrósica produz grandes quantidades de NO, e um nível elevado de nitrito/nitrato tem sido encontrado no líquido sinovial e no soro de pacientes com $\mathrm{OA}^{35}$. O NO pode inibir a síntese de elementos da matriz da cartilagem articular, como o agrecan, aumentar a atividade de MMPs, e reduzir a síntese de IL-1RA pelos condrócitos ${ }^{35}$. A inibição seletiva da NO sintase indutível (iNOS) reduziu a progressão da OA em um modelo experimental de transecção do ligamento cruzado anterior em cães ${ }^{36}$.

\section{Osteoartrite e Dor}

Dor é a manifestação clínica central da OA e a principal razão pela qual os indivíduos afetados procuram por assistência médica. Dada a inexistência atual de terapêuticas eficazes capazes de modificar sua evolução natural, o tratamento da OA é essencialmente o tratamento da dor. Contudo, os mecanismos envolvidos na gênese da dor articular na OA são pouco compreendidos, o que se reflete na baixa eficácia das medicações disponíveis.

Uma das dificuldades na interpretação do fenômeno doloroso na OA é a falta de correlação observada entre lesão estrutural e sintoma. Sabe-se que pessoas com alterações radiográficas compatíveis com OA têm uma chance maior de apresentar dor do que indivíduos sem esse tipo de alteração. Contudo, nem todos aqueles que apresentam alterações 
radiográficas queixam-se de dor. No estudo NHANES-I, por exemplo, dor no joelho foi relatada por $8,8 \%$ dos indivíduos entre 65 e 74 anos com radiografia normal, 20,4\% daqueles com alterações radiográficas grau 1 conforme a classificação de Kellgren-Lawrence (K-L), 36,9\% dos pacientes com K-L grau 2, e $60,4 \%$ dos pacientes com K-L graus 3 e $4^{37}$. Tão importante quanto compreender por que pacientes com OA apresentam dor, é entender por que muitos pacientes com dano articular são assintomáticos ${ }^{38}$.

O descompasso entre estrutura e dor tem implicações para o desenvolvimento de drogas modificadoras de doença, e é um dos fatores limitantes na interpretação do significado de estudos clínicos com candidatos a DMOAs. Demonstrou-se que diacereína ${ }^{39}$, sulfato de condroitina $^{18}$ e doxiciclina $^{40}$, por exemplo, foram capazes de reduzir a taxa de progressão da perda da cartilagem articular sem que tal modificação estrutural tenha se acompanhado de benefício sintomático.

A cartilagem, tecido tido como central na $O A$, não é inervada e, não pode ser a fonte da dor. Vários estudos têm demonstrado a presença de fibras nervosas aferentes na cápsula articular, sinóvia, periósteo, osso subcondral, ligamentos e tendões ${ }^{41}$. Cerca de $20 \%$ dessas fibras nervosas são mielinizadas, sendo que a maioria pertence ao grupo III (fibras Ad) de nociceptores finamente mielinizados, enquanto um número relativamente pequeno de fibras do tipo II (Aß), com maior diâmetro e baixos limiares de ativação, também inerva a articulação. Os outros $80 \%$ são fibras não 
mielinizadas, e cerca de $50 \%$ destas fibras pertencem ao grupo IV (tipo C), sendo as demais eferentes simpáticos ${ }^{42}$.

A rede de fibras nervosas aferentes pode detectar tanto estímulos mecânicos normais como nocivos. A sensação primária nas articulações é a dor, uma vez que a informação sensorial envolvida no sentido de posição e movimento não alcança um nível consciente. As fibras pertencentes aos grupos III e IV constituem-se nos nociceptores primários e apresentam limiar elevado, não sendo ativadas por estímulos do cotidiano ${ }^{41}$. Já as fibras de baixo limiar do tipo II estão associadas ao movimento, propriocepção, e também a dor ${ }^{42}$. Numa situação de inflamação articular, as fibras do grupo II apresentam alterações agudas e transitórias em resposta à manipulação da articulação, resolvendo-se em poucas horas. Já as fibras dos grupos III e IV passam tanto a apresentar atividade espontânea, como se tornam responsivas a estímulos mecânicos externos aos quais eram previamente insensíveis ${ }^{42}$.

Sabe-se que o sistema nervoso atua não apenas como um expectador passivo no processo de nocicepção, transmitindo uma representação do tecido lesado ao centro de dor, mas participa na persistência da dor através do desenvolvimento de mudanças funcionais ou neuroplasticidade ${ }^{43}$. O conceito de neuroplasticidade envolve o aumento na eficácia da condução sináptica, ou sensibilização, através de alterações na localização e expressão de canais iônicos e receptores, e na distribuição e cinética de neurotransmissores e neuromoduladores ${ }^{44}$. Em uma situação de dor, os eventos agudos podem desencadear mecanismos de sensibilização 
do sistema nervoso periférico, medula espinhal e do córtex cerebral, levando a dor crônica. Esse estado de facilitação da condução sináptica pode ser de curta duração, ou ainda persistir por dias, meses, ou mesmo ser irreversível.

Quando um tecido normal é exposto a um estímulo nocivo, a dor resultante reflete a intensidade, a localização e o tempo de aplicação do estímulo. Em tecidos inflamados, a dor pode ocorrer espontaneamente, independente da aplicação de um estímulo externo. Hiperalgesia, com aumento da intensidade de resposta a estímulos nocivos e alodínia, quando estímulos inócuos produzem dor, também são conseqüências dessa inflamação. A dor relacionada aos movimentos na OA pode ser considera um exemplo alodínia mecânica ${ }^{45}$. Mediadores inflamatórios, portanto, têm importante influência na ativação e sensibilização de nociceptores, produzindo tanto alterações precoces pós-translacionais, quanto induzindo alterações de longo prazo por modificações transcricionais e mudanças fenotípicas nas células.

Durante a inflamação aguda, as prostaglandinas, a bradicinina, o fator de crescimento de nervo (NGF), entre outros mediadores inflamatórios, modificam a sensibilidade dos receptores e reduzem o limiar de ativação dos canais iônicos. Esses mediadores também podem levar a alterações transcricionais de longo prazo, que envolvem aumento na produção de receptores, canais iônicos, neurotransmissores e neuromoduladores ${ }^{45}$. Citocinas como TNF-a e IL-1ß induzem hiperalgesia em modelos experimentais, enquanto anticorpos contra essas citocinas estão associados à antinocicepção em modelos animais e em pacientes com artrite 
reumatóide. O mecanismo de hiperalgesia associado a essas citocinas tem sido geralmente atribuído a uma ação indireta, envolvendo a produção de prostaglandinas e outros mediadores. Contudo, algumas evidências recentes sugerem um efeito direto do TNF-a nos nociceptores ${ }^{46}$.

Os mecanismos de sensibilização e neuroplasticidade na dor articular foram caracterizados em modelos experimentais de inflamação intensa e têm papel ainda não definido na $O A$, onde os fenômenos inflamatórios são de pequena intensidade. Algumas observações em pacientes, contudo, têm sugerido a participação de mecanismos de sensibilização do sistema nervoso na gênese da dor na $O A$, o que poderia explicar parcialmente a freqüente dissociação entre lesão estrutural e sintoma ${ }^{47}$. Pacientes com OA de membros inferiores (joelho ou quadril) apresentaram períodos mais prolongados de hiperalgesia e maiores áreas de dor referida após a injeção de salina hipertônica no músculo tibial anterior, quando comparados a controles sem $\mathrm{OA}^{48}$. Pacientes com $\mathrm{OA}$ de joelhos apresentaram um aumento na intensidade da dor desencadeada por pressão em áreas distantes da articulação afetada, nos ombros e nos braços ${ }^{49}$.

Também já foi demonstrado que pacientes com $O A$ de quadril apresentam um menor limiar de dor para pressão aplicada tanto sobre o quadril acometido quanto sobre o quadril contralateral. Mais interessante, contudo, é o fato dessa hiperalgesia ser revertida com a troca da articulação doente por uma prótese de quadrii ${ }^{50}$. Esses mesmos pacientes com OA de quadril também não apresentaram um aumento do limiar de dor quando uma contra-estimulação, um torniquete no membro superior causando dor 
isquêmica, foi aplicada, sugerindo alteração nos mecanismos do controle inibitório nocivo difuso: a aplicação de um estímulo doloroso em um lugar do corpo pode reduzir a dor em outro local. Tal alteração também foi revertida após cirurgia de prótese articular ${ }^{50}$. Dessa forma, a correção da lesão estrutural e a suspensão do estímulo nociceptivo na articulação podem fazer com que os limiares de dor e o controle inibitório central retornem ao normal. Imagens de ressonância nuclear magnética (RNM) têm permitido uma avaliação mais detalhada das alterações estruturais na OA e acrescentado novas informações sobre que estruturas inervadas da articulação estão envolvidas na gênese da dor. Tem sido demonstrada uma associação de alterações do osso subcondral e dor, reacendendo o debate sobre a importância relativa desse tecido e da cartilagem nos fenômenos da articulação artrósica. Em pacientes com OA de joelhos, edema ósseo ("bone marrow edema") esteve presente em $78 \%$ dos pacientes com dor, e em apenas $30 \%$ do grupo sem dor $(p<0,001)^{51}$. Quando essas lesões foram graduadas de 0 a 3 , lesões mais extensas (graus 2 e 3 ) estiveram presentes em $36 \%$ dos com dor versus $2 \%$ dos sem dor $(p<0,001)^{51}$. Estudos histológicos realizados em pacientes com edema óssea na RNM mostraram alterações sugestivas de remodelamento ósseo intenso, além de fibrose e áreas de osteonecrose, e surpreendentemente, pouco ou nenhum edema ${ }^{52}$. A presença de espessamento sinovial na RNM, sugerindo sinovite, bem como a presença de efusão articular, também guardam correlação com dor em pacientes com OA de joelhos ${ }^{41}$. 


\section{Cartilagem Articular}

Ainda que a OA envolva a articulação como um todo, a cartilagem é considerada o tecido central na fisiopatologia da doença, e a condroproteção é tida como o principal alvo para desenvolvimento de DMOAs.

A cartilagem é um tecido hipocelular, e os condrócitos representam apenas 1 a $2 \%$ de seu volume total. Sua matriz extracelular abundante é altamente hidratada e especialmente diferenciada para adaptar-se às funções biomecânicas do tecido. Mais de $70 \%$ do peso da cartilagem é água, e mais de $90 \%$ do seu peso seco corresponde aos dois principais componentes de sua matriz extracelular (MEC), o colágeno tipo II e o $\operatorname{agrecan}^{53}$. Diversas outras moléculas fazem parte da organização da MEC da cartilagem, e incluem, por exemplo, colágenos menores (tipo IX, XI, VI, X, XII e XIV), outros proteoglicanos (decorina, biglican, perlecan, versican), ácido hialurônico, proteína de ligação, COMP, tenascina, fibronectina, dentre outras $^{53}$. A MEC da cartilagem articular apresenta não apenas um papel estrutural, mas seus elementos interagem com receptores da superfície dos condrócitos, regulando a função dos mesmos. Esses receptores incluem principalmente integrinas, CD-44 e anexinas. Essa interação célula-matriz é importante para os mecanismos de mecanotransdução na cartilagem articular, bem como para a manutenção da homeostasia do tecido ${ }^{53}$.

A integridade da rede colágena e do agrecan é essencial para manutenção das propriedades biomecânicas da cartilagem articular. O agrecan é uma molécula rica em cargas negativas associadas aos 
glicosaminoglicanos, sendo portanto altamente hidrofílica, e gerando uma pressão de hidratação na MEC. Essa pressão de hidratação é contrabalanceada e restringida pela rede de colágeno. A fibra de colágeno da cartilagem é heterotípica, formada principalmente pelos colágenos II, IX e XI. O colágeno tipo II forma o arcabouço das fibrilas; o colágeno tipo XI está localizado no interior das fibrilas, sendo fundamental para a fibrilogênese, enquanto o colágeno tipo IX está situado na superfície das fibrilas colágenas, atuando como uma "cola" que liga diferentes fibrilas de colágeno entre si através de interações com o colágeno tipo II, bem como participando da interação das fibras colágenas com proteoglicanos e outros elementos da matriz extracelular ${ }^{54}$.

O agrecan, principal proteoglicano (PG) da MEC da cartilagem, é uma molécula complexa, formada por um centro proteico ao qual se ligam covalentemente cerca de 100 cadeias de glicosaminoglicanos (GAGs). O agrecan forma um complexo ternário na cartilagem que envolve o próprio agrecan, ácido hialurônico $(\mathrm{AH})$ e proteína de ligação (LP). O centro proteico consiste de três domínios globulares, G1,G2 e G3, e três domínios interglobulares, os domínios de ligação do keratan-sulfato (KS) e do condroitin-sulfato (CS), localizados entre G2 e G3, e um pequeno domínio interglobular entre G1 e G2. A interação entre o agrecan, LP e AH se dá na região do domínio $\mathrm{G} 1^{55}$.

Glicosaminoglicanos são polissacarídeos lineares formados por repetição de um dissacarídeo, o qual é composto por um açúcar aminado e um ácido urônico. O agrecan é formado por cerca de 100 cadeias de CS e 
15 a 25 cadeias de KS. No caso do condroitin-sulfato (CS), esse dissacarídeo é formado pela $\mathrm{N}$-acetil galactosamina e pelo ácido glicurônico. A N-acetil-galactosamina pode ser sulfatada na posição 4 ou na posição 6 , formando os dois isômeros do condroitin-sulfato presentes na cartilagem articular: condroitin -4-sulfato (CS4) e condroitin-6-sulfato (CS6). O polímero final formado pelo CS, apresenta em média 40 repetições desse dissacarídeo na cartilagem humana, o que equivale a um peso molecular de aproximadamente $20 \mathrm{KDa}^{56,57}$.

Um fenômeno bem conhecido dos polissacarídeos biológicos é a microheterogeneidade ${ }^{57}$. Uma preparação de GAG extraída de um tecido conjuntivo apresenta, portanto, uma população heterogênea de moléculas, tanto com diferentes tamanhos de cadeia, como com diferentes padrões de sulfatação. Essa microheterogeneidade é responsável pelos padrões de dispersão encontrados quando esses polímeros são avaliados por métodos como eletroforese em gel de poliacrilamida e diversos métodos de cromatografia $^{57}$. O significado biológico desta microheterogeneidade não está bem esclarecido, mas provavelmente resulta do processo de síntese desses compostos no retículo endoplasmático e no complexo de Golgi, onde são sintetizados a partir de monossacarídeos precursores, e ligados ao centro proteico à medida que este é sintetizado ${ }^{57}$. Uma alteração no perfil do tamanho molecular dos GAGs da cartilagem articular, em especial do condroitin sulfato, que é o GAG mais abundante, provavelmente trará alterações para a sua biomecânica, em decorrência de mudanças na 
densidade de cargas negativas, afetando a pressão de hidratação do tecido e sua compressibilidade.

A cartilagem possui uma estrutura heterogênea, com quatro regiões reconhecíveis, as quais apresentam diferenças na forma e orientação dos condrócitos, bem como na composição das macromoléculas da MEC: a zona superficial ou tangencial, a zona média ou de transição, a zona profunda ou radial, e a cartilagem calcificada $^{58}$. A cartilagem apresenta ainda uma compartimentalização que reflete a área de influência dos condrócitos sobre a $\mathrm{MEC}^{58,59}$. A matriz pericelular, imediatamente adjacente à membrana plasmática dos condrócitos, é formada por grandes quantidades de agrecan e relativamente poucas fibras colágenas. Os agregados do proteoglicano se ligam à célula por interação do ácido hialurônico, e possivelmente também do condroitin-sulfato, com receptores CD-44. Contiguamente à matriz pericelular, está a matriz territorial, formada por uma rede de fibras colágenas que envolvem a célula ou grupos de células. O colágeno tipo ॥ nesta região interage com processos citoplasmáticos dos condrócitos através de moléculas de membrana, como a anexina $\mathrm{V}$ (ou ancorina CII) e a integrina $a 2 B 1^{58,59}$. Esses dois compartimentos definem a matriz extracelular sob a qual os condrócitos exercem controle metabólico ativo, enquanto a MEC interterritorial, que está localizada mais distante das células e contém a maior parte das fibras colágenas e do agrecan, é mais inerte metabolicamente ${ }^{58,59}$.

As alterações histopatológicas encontradas na articulação artrósica são inicialmente focais e localizadas principalmente em áreas de maior 
sobrecarga mecânica na superfície articular. Porém, à medida que a doença progride, as lesões se estendem horizontalmente na articulação, podendo afetar extensas áreas do tecido. As lesões mais precoces limitam-se às regiões mais superficiais, progredindo em gravidade com o acometimento progressivo de regiões mais profundas, o que pode resultar em áreas de perda completa do tecido e exposição do osso subcondral. A progressão dessas alterações pode ser graduada semi-quantitativamente permitindo acompanhar sua evolução e avaliar a resposta de DMOAs.

Um desses sistemas recém descrito classifica a gravidade da lesão em seis graus ${ }^{60}$. Grau 1 caracteriza-se por fibriliação superficial, edema focal ou generalizado da cartilagem, proliferação e hipertrofia dos condrócitos, com formação de clusters (aglomerados), e perda da orientação normal das células. Necrose e apoptose dos condrócitos, com condrons vazios ou "fantasmas", já podem ser observadas. Grau 2 caracteriza-se por exfoliação, ou destacamento de fragmentos de cartilagem da camada superficial, com redução da coloração da matriz pela safranina $\mathrm{O}$ ou azul de toluidina, refletindo perda de proteoglicanos, nas regiões mais superficiais da cartilagem. Tanto a proliferação como morte dos condrócitos acentuam-se com a progressão da doença. No grau 3, as fissuras se estendem até a zona de transição, com heterogeneidade da matriz, e áreas de coloração acentuada intercaladas com áreas de intensa depleção do corante (safranina e toluidina). As alterações dos condrócitos tornam-se muito evidentes, com maior proliferação e desorientação, e também mais morte celular, principalmente nas regiões próximas às fissuras. No grau 4 aparecem 
regiões de delaminação do tecido e áreas de escavação, com erosões profundas e por vezes coalescentes. Ocorre intensa perda da coloração por safranina $\mathrm{O}$ e azul de toluidina, e tanto as alterações proliferativas quanto associadas à morte dos condrócitos continuam evidentes. Fragmentos que se desprendem da cartilagem podem por vezes ser visualizados como corpos livres. O grau 5 caracteriza-se por áreas de desnudamente, com exposição do osso subcondral subjacente, enquanto o grau 6 se caracteriza por deformidades do osso subcondral.

A lesão da cartilagem articular progride num ambiente em que tanto ocorre catabolismo e degradação, como anabolismo e tentativa de reparo pelos condrócitos. A síntese de proteoglicanos, colágeno, proteínas não colagenosas e DNA está significativamente aumentada na cartilagem artrósica, mantendo-se aumentada até as fases mais avançadas da doença, explicando a lenta progressão do dano da cartilagem na OA. A destruição dos elementos da MEC envolve a liberação de colagenases (MMP-1, MMP-8 e MMP-13), agrecanases (ADAMTS -4 e ADAMTS-5), plasmina, catepsina B, dentro outras enzimas. Os fenômenos de degradação e síntese são modulados por citocinas, em particular TNF-a e IL-1, e por fatores de crescimento, como IGF-1 e BMPs, além dos inibidores das MMPs $(\text { TIMPs) })^{27,61}$.

O desbalanço na síntese e degradação de PG é muito importante na patogênese do dano da cartilagem. Em particular, a síntese de PG na OA produz moléculas qualitativamente diferentes daquelas da cartilagem articular adulta normal, alterações estas que englobam tanto a composição e 
distribuição de GAGs, como o tamanho do centro proteico e sua capacidade de se ligar ao ácido hilaurônico ${ }^{62,63}$. A concentração do KS cai na cartilagem artrósica, enquanto a taxa CS4 /CS6 aumenta, simulando o perfil mais característico de uma cartilagem imatura ${ }^{63,64}$. A concentração de PG cai progressivamente com o avanço da doença ${ }^{62}$.

\section{Sulfato de glicosamina e Sulfato de Condroitina}

Avanços na compreensão da fisiopatologia da osteoartrite, e a caracterização da importância de mediadores inflamatórios e bioquímicos na progressão do dano articular poderão propiciar, em um futuro próximo, terapêuticas direcionadas para alvos específicos, como TNF-a, IL-1 e MMPs. Contudo, antes mesmo da compreensão dessas vias de degradação da cartilagem articular, tentativas de modificar a progressão do dano estrutural da doença foram baseadas na premissa empírica de que a administração de precursores da matriz extracelular pudessem ajudar os condrócitos a repor o tecido lesado. Essa premissa levou ao uso de glicosamina, condroitina e ácido hialurônico no tratamento da $O A^{65}$.

Segundo uma atualização das recomendações para o desenvolvimento de drogas modificadoras de doença no tratamento da $\mathrm{OA}^{66}$, para que uma droga seja considerada como DMOA, deve tanto modular a perda do espaço articular quanto demonstrar benefício em desfechos clínicos relevantes. Apesar de o tempo para prótese articular 
pode ser considerado possivelmente como o melhor desfecho para estudos clínicos com drogas modificadoras de doença, não existem critérios totalmente estabelecidos para indicação de prótese, e esta permanece como uma decisão subjetiva e influenciada por fatores não relacionados à evolução natural da $O A$, como preferências individuais do médico e do paciente, e presença de comorbidades, não podendo ainda ser recomendada como desfecho para DMOAs ${ }^{67}$. Assim, melhora da dor e da função são pré-requisitos para que uma droga possa ser considerada modificadora estrutural na OA.

Recomendações tanto do ACR (“American College of Rheumatology”) como da EULAR (“European Ligue Against Rheumatism”) não reconhecem nenhuma droga como agente modificador de doença na $O A^{68,69}$. Segundo a recomendação da EULAR, porém, sulfato de glicosamina é tido como a droga para a qual existe o maior nível de evidência e força de recomendação para seu uso $^{69}$. Contudo, não existe consenso, e o benefício tanto de glicosamina como sulfato de condroitina é controverso na literatura.

Dois estudos clínicos bem desenhados demonstraram propriedades modificadoras de doença para o sulfato de glicosamina. Pacientes com OA de joelhos tratados com sulfato de glicosamina mostraram menor progressão da perda do espaço articular radiográfico, uma medida indireta de perda da cartilagem articular ${ }^{16,17}$. Essa condroproteção foi acompanhada de melhora sintomática nesses dois estudos. Contudo, críticas em relação à metodologia utilizada para obtenção das radiografias de joelho têm questionado esses resultados. $\mathrm{Na}$ época, recomendava-se a radiografia de joelhos em 
extensão, contudo, evidências posteriores mostraram que essa forma de obter as imagens é inadequada, não avaliando as regiões posteriores da articulação, sofrendo considerável influência dos meniscos na composição do espaço articular, e apresentando variações significativas de posicionamento em exames seriados, de forma que atualmente recomendase o uso da posição em semiflexão do joelho ${ }^{70}$. Uma outra crítica em relação aos estudos curiosamente se utiliza de uma de suas forças, que foi a melhora sintomática. Especula-se que os pacientes do grupo placebo tenham estendido menos o joelho na obtenção das radiografias por apresentarem mais dor do que os tratados com sulfato de glicosamina, falseando a medida do espaço articular. Tais especulações, no entanto, não foram confirmadas ${ }^{71}$.

Além dos questionamentos em relação ao efeito estrutural, sobre os quais ainda não há consenso definitivo, dúvidas em relação à eficácia sintomática também têm sido levantadas. Existem discrepâncias de resultados em estudos utilizando diferentes formulações e diferentes esquemas posológicos. Em uma metanálise da Cochrane ${ }^{72}$, vinte estudos clínicos foram selecionados, e como um todo, mostraram benefício de glicosamina sobre a dor e a função. Contudo, os resultados dos estudos não foram uniformes, e somente nos estudos que utilizaram o sulfato de glicosamina formulado pela Rottapharma ${ }^{\circledR}$, administrado uma vez por dia, observou-se benefício, enquanto em estudos que utilizaram cloridrato de glicosamina, com posologia três vezes por dia, ou outras formulações do sulfato de glicosamina, não mostraram benefício ${ }^{72}$. 
Em relação ao sulfato de condroitina, três metanálises ${ }^{73,74,75}$ concluíram por benefício sintomático do composto. Entretanto, um estudo mais recente não foi incluído nessas metanálises. Nesse estudo, a administração de $800 \mathrm{mg}$ de sulfato de condroitina uma vez por dia reduziu significativamente a progressão da redução do espaço articular radiográfico obtido com radiografias em semiflexão em pacientes com $\mathrm{OA}$ de joelhos ${ }^{18}$. Contudo, não houve melhora da dor. O benefício da associação de glicosamina e condroitina sobre as drogas isoladas também não está definido.

Dois estudos recém divulgados trouxeram novos elementos para essas controvérsias. No estudo GAIT ("Glucosamine/chondroitin Arthritis Intervention Trial"), utilizou-se cloridrato de glicosamina, e não sulfato de glicosamina. Cloridrato de glicosamina $500 \mathrm{mg}$ três vezes por dia, sulfato de condroitina $400 \mathrm{mg}$ três vezes por dia, ou os dois compostos em combinação, não mostraram benefício sintomático em relação a dor e função em pacientes com OA de joelhos seguidos por 6 meses $^{76}$. Uma análise post hoc, porém, mostrou benefício da combinação no subgrupo de pacientes com dor moderada a grave ${ }^{76}$. Alguns autores sugerem que a alta taxa de resposta ao placebo $(60,1 \%)$ possivelmente contribuiu para os achados negativos dos compostos $^{77}$. Um outro estudo multicêntrico, GUIDE ("Glucosamine Unum in Die Efficacy), utilizando a prescrição original de $1500 \mathrm{mg}$ de sulfato de glicosamina uma vez por dia, por sua vez, demonstrou melhora no índice de Lequesne para dor e funçao ${ }^{78}$. Apesar de haver comentários de que as diferenças observadas possam guardar 
relação com patrocínio pela indústria farmacêutica, muitos autores acreditam que não haja elementos para sustentar esse argumento, e que diferenças na população estudada, na gravidade da dor, no desenho dos estudos, forma de avaliação, e na posologia e formulação das drogas possam explicar essas diferenças ${ }^{77}$.

Dados relacionados à farmacocinética e mecanismo de ação dos compostos têm contribuído para as dúvidas relacionadas à sua eficácia. Estudos utilizando uma dose única via oral de sulfato de glicosamina mostraram que a concentração alcançada no soro dos pacientes fica abaixo da necessária para que tenha efeito sobre a célula ${ }^{79}$. Contudo, a administração de sulfato de glicosamina 1500 mg/dia via oral por três dias alcança uma concentração no soro e no líquido sinovial de $10 \mu \mathrm{M}$, concentração suficiente para que se observem efeitos em condrócitos em cultura $^{80}$. A farmacocinética do sulfato de condroitina é menos clara, e esse composto pode ser absorvido na forma de vários metabólitos, de forma que o componente ativo não foi ainda identificado ${ }^{81}$.

A incorporação desses compostos aos proteoglicanos da cartilagem articular, tida como um dos seus possíveis mecanismos de ação, é questionável. A detecção de marcadores radioativos na articulação após a ingestão de sulfato de glicosamina marcada, não necessariamente indica que a glicosamina é o carreador dessa radiação ${ }^{82}$. Ainda, a via de síntese dos glicosaminoglicanos da matriz extracelular da cartilagem utiliza preferencialmente a glicose como substrato, e aparentemente as concentrações alcançadas pela glicosamina na articulação não fariam com 
que esta influenciasse a biossíntese desses $\mathrm{GAGs}^{82}$. A ação proposta para esses compostos parece envolver propriedades antiinflamatórias, as quais foram demonstradas em culturas de condrócitos, como por exemplo, redução da produção de $P G E 2^{83,84}$, da ativação do $N F ? B^{85}$ e da liberação do $\mathrm{NO}^{84}$.

Em relação a estudos em modelos experimentais de OA, os resultados também não são definitivos. A administração oral de cloridrato de glicosamina a coelhos submetidos a TLCA não preveniu a erosão da cartilagem articular ${ }^{86}$. Em coelhos submetidos à ressecção do ligamento cruzado anterior e posterior e meniscectomia, a administração de cloridrato de glicosamina e sulfato de condroitina não melhorou os parâmetros histológicos avaliados, enquanto a associação dos dois compostos reduziu a degradação da cartilagem ${ }^{87}$. Nenhum estudo em modelos experimentais de OA avaliou ainda o efeito de sulfato de glicosamina sobre a lesão da cartilagem articular, questão relevante uma vez que aparentemente sulfato e cloridrato de glicosamina apresentam eficácia diferentes.

\section{Transecção do ligamento cruzado anterior em ratos}

Um dos aspectos limitantes no estudo da OA em humanos é inexistência de métodos objetivos e confiáveis para avaliar a evolução da progressão da doença em estudos clínicos. As dificuldades incluem disponibilidade de tecido para análise histopatológica, em particular nas 
fases iniciais da doença, a ausência de marcadores biológicos confiáveis, e a não padronização em definitivo de métodos de imagem, tanto da radiografia quanto da ressonância magnética. Por esta razão, modelos experimentais em animais continuam sendo amplamente utilizados tanto para a compreensão de aspectos fisiopatológicos da doença como para a avaliação pré-clínica de novos fármacos e terapias.

Diversos modelos em diferentes espécies animais têm sido utilizados. De uma forma geral, esses podem ser classificados em espontâneos, geneticamente induzidos, induzidos cirurgicamente, ou por injeção de substâncias químicas na articulação. Não existe atualmente um modelo ideal que englobe de forma precisa todos os aspectos da doença humana, e cada um deles apresenta vantagens e desvantagens ${ }^{88}$.

Animais que desenvolvem OA espontaneamente provavelmente são os que melhor expressam a lenta evolução da OA humana. Contudo, exigem um tempo muito longo de observação, e apresentam progressão variável, dificultando seu uso para a comparação de tratamentos. Já modelos em camundongos geneticamente modificados, como por exemplo knockout para o gene Col2a1 ou para ADAMTS-5, permitem avaliar o papel de moléculas específicas na fisiopatologia da doença, mas provavelmente não são adequados para avaliação pré-clínica de DMOAs. Em modelos de OA induzidos cirurgicamente ou quimicamente, o dano articular se desenvolve de forma rápida e previsível. No entanto, esses modelos são mais compatíveis com OA secundária, e os animais podem desenvolver lesão 
agressiva, dificultando a avaliação de drogas capazes de modificar a evolução da doença ${ }^{88}$.

A transecção do ligamento cruzado anterior (TLCA) tem sido estudada em diversas espécies, como coelhos e cães. A TLCA em ratos foi descrita em 1987, tendo sido demonstradas alterações histológicas na cartilagem articular semelhantes à OA humana e a modelos de TLCA em outras espécies $^{89}$. Alterações compatíveis com OA ocorrem de forma precoce, com edema e perda de condrócitos, em associação a fibrilação da cartilagem articular, já aos sete dias após a TLCA ${ }^{21}$. O dano da cartilagem ocorre de forma bifásica, com uma fase precoce, na qual as lesões se concentram nas regiões periféricas da articulação, e uma fase posterior, onde as lesões surgem nas áreas centrais dos côndilos femorais e do platô tibial ${ }^{90}$. As lesões iniciais começam na região superficial e se aprofundam na cartilagem, com redução de proteoglicanos e desnaturação do colágeno tipo II, porém sem aumento expressão de neoepítopos por degradação pela colagenase, sugerindo que esta enzima não participa efetivamente da degeneração da cartilagem nesse modelo ${ }^{21}$.

Além das alterações na cartilagem, este modelo apresenta remodelação óssea, caracterizada inicialmente por perda do osso subcondral, detectada duas semanas após a cirurgia, com posterior aumento de volume do mesmo, além da presença evidente de osteófitos dez semanas após a TLCA ${ }^{91}$. De fato o modelo já foi utilizado para avaliar a relevância dessa remodelação do osso subcondral na progressão do dano da cartilagem articular, e a administração de alendronato aos animais, com 
supressão da reabsorção óssea inicial e do aumento posterior da formação óssea, foi associada à condroproteção ${ }^{92}$.

Dessa forma, a TLCA em ratos constitui-se em um bom modelo experimental de $\mathrm{OA}$, apresentando alterações tanto da cartilagem como do osso subcondral compatíveis com a doença humana, e sendo passível de modificação estrutural por intervenção farmacológica. A utilização do rato, além do baixo custo, facilidade para manutenção e baixa incidência de infecção associada a procedimentos cirúrgicos ${ }^{89}$, traz ainda a possibilidade de controlar a intensidade das alterações da cartilagem articular através de exercícios forçados, os quais são facilmente aplicáveis a essa espécie. Lesões compatíveis com OA foram mais freqüentes nos animais submetidos a exercício forçado numa esteira após a TLCA, do que em animais que não foram submetidos a esse esforço ${ }^{89}$. Em um outro estudo onde os animais foram submetidos a três intensidades diferentes de exercício numa esteira (leve, moderado e intenso) após a TLCA, observou-se redução significativa do dano da cartilagem articular nos grupos leve e moderado, o que não foi observado nos animais submetidos ao esforço intenso ${ }^{93}$.

Esses resultados, além de oferecerem a possibilidade de estudar os efeitos da sobrecarga mecânica sobre eventos bioquímicos e celulares em um modelo experimental de OA, permitem que o mesmo modelo possa ser utilizado para gerar lesões cartilaginosas de diferentes intensidades ${ }^{88}$.

Ainda que a dor e a limitação de movimentos sejam os principais sintomas da $\mathrm{OA}$, esses aspectos não tinham sido investigados em modelos experimentais de $\mathrm{OA}$ até recentemente. Com o objetivo de estudar uma 
lesão funcional da articulação, e usando a experiência acumulada no modelo de artrite por zymosan em ratos $^{24}$, utilizamos o teste de incapacitação articular para avaliação de ratos submetidos à TLCA. Nossos resultados mostraram de forma inédita que os animais submetidos à TLCA desenvolvem incapacitação articular entre o primeiro e o décimo quarto dia pós-TLCA, e que esta incapacitação é máxima na primeira semana. A administração profilática de indometacina e meloxicam reduziu significativamente o TSP, assim como a administração de morfina, o que demonstra que o comportamento observado reflete dor (hipernocicepção) e não apenas instabilidade $\operatorname{articular}^{22}$. 


\section{OBJETIVOS}

1. Avaliar o efeito de sulfato de glicosamina, e de sua associação com sulfato de condroitina, sobre a incapacitação articular no modelo de osteoartrite induzida por transecção do ligamento cruzado anterior em ratos.

2. Avaliar o efeito de sulfato de glicosamina, e de sua associação com sulfato de condroitina, sobre a lesão da cartilagem articular no modelo de osteoartrite induzida por transecção do ligamento cruzado anterior em ratos.

3. Caracterizar desenvolvimento de dor articular nas fases crônicas do modelo 


\section{MATERIAIS E MÉTODOS}

\section{Animais}

Foram utilizados ratos Wistar machos, pesando entre 180 e 200 gramas, fornecidos pelo Biotério Central da Universidade Federal do Ceará. Os animais foram mantidos em caixas plásticas padrão com no máximo quatro animais por caixa, e receberam água e alimentação ad libidum. Todos os esforços foram feitos para minimizar o número e o sofrimento dos animais utilizados. O protocolo experimental foi aprovado pelo comitê de ética em experimentação animal, sendo conduzido conforme as normas do Colégio Brasileiro de Experimentação Animal.

\section{Drogas}

Foram utilizados Dinaflex ${ }^{\circledR}$ (Zodiac Tecnofarma Brasil Ltda), na apresentação de $1500 \mathrm{mg}$ de sulfato de glicosamina por sachê, e Artrolive ${ }^{\circledR}$ (Ache Laboratórios Farmacêuticos S.A.), na apresentação de cápsulas contendo sulfato de glicosamina $500 \mathrm{mg}$ em associação com sulfato de condroitina $400 \mathrm{mg}$. As drogas foram compradas em uma farmácia local, e não houve participação ou patrocínio dos fabricantes na realização do presente trabalho. 
Transecção do Ligamento Cruzado Anterior (modificado de Stoop et al., 2001)

Os animais foram anestesiados com hidrato de cloral $(200 \mathrm{mg} / \mathrm{kg})$ por via intraperitoneal. Após depilação e anti-sepsia da região, foi realizada uma incisão longitudinal na pele sobre o joelho direito. Foi feita então uma incisão parapatelar lateral, e o tendão patelar foi rebatido medialmente, dando acesso à cavidade articular. Uma vez visualizado o ligamento cruzado anterior, o mesmo foi cuidadosamente seccionado com uma tesoura microcirúrgica, evitando-se ao máximo lesionar outras estruturas articulares. O livre movimento do fêmur em relação à tíbia no sentido póstero-anterior ("sinal da gaveta") confirma a secção do ligamento. O tendão patelar foi reposicionado, e a incisão suturada com fio absorvível $\left(V_{y c r i{ }^{\Theta}}{ }^{(5 / 0)}\right.$. A pele foi suturada com $\mathrm{Nylon}^{\circledR} 4 / 0$. Os pontos da pele foram retirados após sete dias. Animais nos quais a ferida cirúrgica sofreu deiscência ou apresentou sinais de infecção foram excluídos. Grupos falso-operados (SHAM) foram submetidos ao mesmo procedimento cirúrgico, exceto a transecção do ligamento.

\section{Avaliação da incapacitação articular (dor articular)}

O efeito antinociceptivo de sulfato de glicosamina e da associação sulfato de glicosamina / sulfato de condroitina foi avaliado através do teste de incapacitação articular para ratos ${ }^{22}$. Nesse teste, os animais são postos 
para deambular em um cilindro giratório de alumínio, com $30 \mathrm{~cm}$ de diâmetro e $50 \mathrm{~cm}$ de largura, com capacidade para três animais por vez (fotografia 1). O cilindro gira a uma velocidade constante de três rpm. As patas traseiras dos animais são calçadas com sapatilhas metálicas especialmente desenhadas. A sapatilha direita - correspondente à pata submetida à artrotomia - é conectada a um sistema computadorizado de aquisição de dados. Ao tocar o cilindro com a pata, o animal fecha um circuito, que é registrado pelo computador. O programa fornece então o tempo em que o animal mantém a pata direita suspensa ao deambular no cilindro durante dez minutos. Esse tempo de suspensão da pata (TSP) é proporcional à dor articular nesse modelo. Foi demonstrado que os animais submetidos à TLCA desenvolvem dor articular entre o quarto (D4) e o décimo quarto (D14) dias após a cirurgia, porém padronizou-se que a avaliação é feita com base na média do maior valor do TSP para cada grupo de animais, mensurado entre o quarto e o sétimo dias pós-cirurgia, período em que a dor articular mostrou-se mais intensa ${ }^{22}$.

Durante o presente experimento, o período de avaliação dos animais foi estendido até 70 dias. Os animais foram submetidos ao teste de incapacitação articular diariamente entre o primeiro (D1) e o vigésimo oitavo dias pós-TLCA. Após esse período, foram avaliados duas vezes por semana, até o sacrifício no D70. Para avaliação do efeito antinociceptivo de sulfato de glicosamina e sulfato de glicosamina / sulfato de condroitina, o registro do TSP foi feito 30 minutos após a administração dos compostos. Como controle positivo do experimento, um grupo de animais submetido a 
TLCA recebeu meloxicam $6 \mathrm{mg} / \mathrm{kg}$ subcutâneo, meia hora antes da avaliação do TSP. Os resultados são expressos como a média \pm erro padrão da média (EPM) do TSP (seg /10 minutos) máximo obtido entre D4 e D7 pós-TLCA para grupos de pelo menos nove animais.

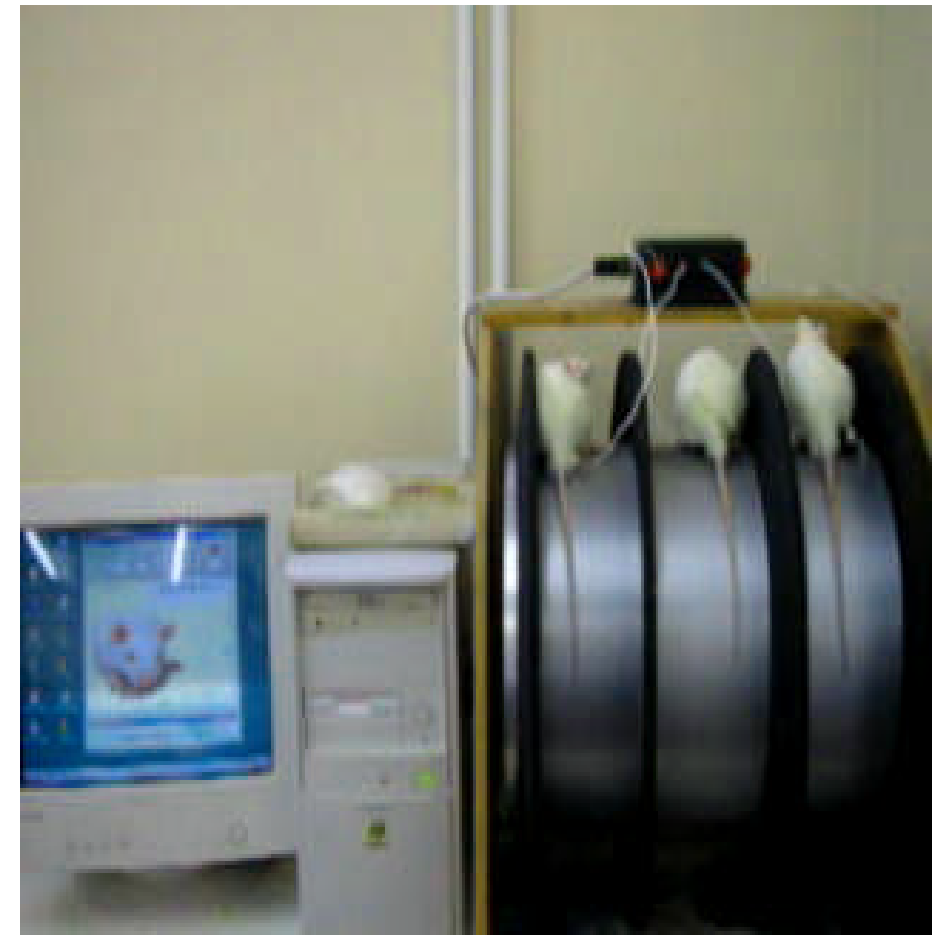

Fotografia 1- Teste de incapacitação articular para ratos. Os animais são colocados para deambular em um cilindro metálico que gira a $3 \mathrm{rpm}$, e a pata traseira direita é conectada a um sistema informatizado de aquisição de dados que fornece o tempo durante o qual o animal deambula com a pata levantada (TSP). 


\section{Tratamentos}

Grupos de nove animais foram tratados com sulfato de glicosamina $500 \mathrm{mg} / \mathrm{kg}$ (grupo Glu) ou a combinação de sulfato de glicosamina 500 $\mathrm{mg} / \mathrm{kg}$ e sulfato de condroitina $400 \mathrm{mg} / \mathrm{kg}$ (grupo GluChon), desde sete dias antes da TLCA até o sacrifício no D70. As drogas foram diluídas em solução salina estéril a $0,9 \%$ de modo que a dose correspondente a cada animal estivesse em um volume máximo de $1,5 \mathrm{ml}$, e administradas via oral por gavagem após uma hora de jejum. Os compostos foram administrados diariamente, inclusive em finais de semana e feriados. Um grupo controle submetido a TLCA (grupo OANT) e um grupo falso-operado (grupo SHAM) foram tratados da mesma forma apenas com solução salina estéril.

\section{Coleta do líquido sinovial e das extremidades femorais}

Os animais foram sacrificados em diferentes períodos após a cirurgia: sete, quatorze, vinte e oito e setenta dias. A eutanásia foi realizada por anestesia terminal com hidrato de cloral $(400 \mathrm{mg} / \mathrm{kg})$ e decapitação. Após o sacrifício, a cavidade articular do joelho direito foi lavada com $0,4 \mathrm{ml}$ de PBS contendo $10 \mathrm{mM}$ de EDTA, e o líquido sinovial colhido por aspiração. O líquido coletado foi centrifugado $\left(500 \mathrm{~g} / 10 \mathrm{~min} / 4^{\circ} \mathrm{C}\right)$ e o sobrenadante conservado a $-20^{\circ} \mathrm{C}$ para posterior determinação do nitrito total, o que foi realizado nos animais de sete dias. 
Nos animais observados por setenta dias, as extremidades femorais distais dos joelhos direitos de quatro ratos em cada grupo foram separadas após dissecção dos músculos e ligamentos, fixadas em formol a 10\% por 24 horas, e então descalcificadas em uma solução de ácido fórmico a 10\% por 14 dias. Os dois côndilos femorais (lateral e medial) foram separados com um bisturi e incluídos em parafina. Foram realizados cortes histológicos seriados $(5 \mu \mathrm{m})$ no plano sagital da superfície articular, da porção mais externa para a porção mais interna de cada côndilo. A cada 10 cortes (portanto a cada $50 \mu \mathrm{m}$ ), um corte histológico era coletado em duplicata para coloração com hematoxilina e eosina (H\&E) ou azul de toluidina, com cinco sítios diferentes para cada côndilo. Dessa forma, para cada articulação eram obtidas 10 lâminas coradas por H\&E e 10 lâminas coradas por azul de toluidina.

Nos grupos experimentais de sete, quatorze, vinte e oito e setenta dias, a cartilagem das extremidades femorais distais de pelo menos cinco animais em cada grupo foi cuidadosamente retirada com uma lâmina de bisturi sob visualização com uma lupa. Após secagem em estufa a $80^{\circ} \mathrm{C}$ por 12 horas, foi medido peso seco das cartilagens, e as amostras foram guardadas em acetona para posterior quantificação dos glicosaminoglicanos (GAGs). 


\section{Extração dos GAGs da cartilagem articular}

A cartilagem seca retirada dos côndilos femorais foi homogenizada e posteriormente submetida a proteólise enzimática total com Prolav750 ${ }^{\circledR} \mathrm{em}$ tampão Tris/HCl/ $\mathrm{NaCl} 50 \mathrm{mM} / 150 \mathrm{mM}$ (4 mg enzima / $\mathrm{ml}$ do tampão), em pH 8,0 , a $56^{\circ} \mathrm{C}$, por 48 horas, conforme descrito previamente ${ }^{23}$. Concluída a proteólise, corrigiu-se a concentração de $\mathrm{NaCl}$ para $1 \mathrm{M}$, mantendo-se as amostras por 30 minutos a $37^{\circ} \mathrm{C}$. Em seguida, ácido tricloroacético (TCA) foi adicionado até obtenção de uma concentração final de 10\%, após o que as amostras foram submetidas a agitação a $4^{\circ} \mathrm{C}$ por 15 minutos, e então centrifugadas $\left(10.000 \mathrm{~g} / 15 \mathrm{~min} / 4^{\circ} \mathrm{C}\right)$. O precipitado foi descartado e ao sobrenadante foram acrescidos dois volumes de metanol. As amostras foram mantidas overnight a $4^{\circ} \mathrm{C}$ para precipitação dos GAGs. Após nova centrifugação $\left(10.000 \mathrm{~g} / 15 \mathrm{~min} / 4^{\circ} \mathrm{C}\right)$, o sobrenadante foi descartado e o precipitado ressuspenso em $20 \mu \mathrm{l}$ de água destilada. O resíduo de cartilagem foi lavado, seco em estufa, e pesado para determinação da massa de cartilagem realmente degradada. Após esse protocolo, a digestão com condroitinases identificou o condroitin-sulfato (CS) como o único GAG extraído ${ }^{23}$. O termo condroitin-sulfato (CS) utilizado no presente estudo inclui a quantidade total de condroitin-4-sulfato e condroitin-6-sulfato, uma vez que os métodos utilizados não permitem a distinção entre esses dois isômeros. 
Quantificação dos GAGs da cartilagem articular por eletroforese em gel de agarose

Os GAGs extraídos da cartilagem articular foram submetidos a eletroforese em gel de agarose para separação e quantificação, conforme descrito previamente ${ }^{22,94}$. Cinco microlitros do material ressuspenso em água foram aplicados em gel de agarose a 0,6\% em tampão PDA $(\mathrm{pH}=9,0)$. A separação foi feita por eletroforese vertical realizada em uma diferença de potencial de 100 volts, com aproximadamente 1 hora e meia de duração. Após a migração, o CS foi precipitado no gel por imersão em CTV (brometo de cetil-trimetilamônio) a $0,1 \%$ por 2 horas. O gel foi seco sob calor e ventilação, e corado com solução hidroalcoólica ácida de azul de toluidina $0,1 \%$ por 15 minutos. O excesso de corante foi removido por uma solução descorante. A identificação e quantificação dos GAGs foi feita por comparação com padrões conhecidos de condroitin-sulfato e heparan-sulfato através de densitometria $(525 \mathrm{~nm})$. Os resultados $(\mu \mathrm{g}$ de $\mathrm{CS} / \mathrm{mg}$ de cartilagem seca) são expressos como a média £ EPM para cada grupo.

\section{Avaliação do peso molecular das cadeias de CS extraídas da cartilagem articular por eletroforese em gel de poliacrilamida}

Após a quantificação do CS da cartilagem por eletroforese em gel de agarose, o equivalente a $10 \mu \mathrm{g}$ de CS de cada amostra foi aplicado em gel 
de poliacrilamida ( $6 \%$ w/v em tampão barbital $60 \mathrm{mM}, \mathrm{pH} 8,60)$ e submetido a eletroforese vertical sob uma diferença de potencial de 100 volts. Após a migração, o CS foi fixado no gel por imersão em uma solução de brometo de CTV $0,1 \% \mathrm{w} / \mathrm{v}$, por 2 horas, seguindo-se a coloração por azul de toluidina $(0,1 \% \mathrm{w} / \mathrm{v}$ em ácido acético a $1 \% \mathrm{v} / \mathrm{v})$ durante $15 \mathrm{~min}$. O excesso de corante foi removido por imersão em ácido acético a $1 \%$ v/v por 3 horas. Para secagem, o gel foi imerso em solução de glicerol $5 \% \mathrm{v} / \mathrm{v}$ por $30 \mathrm{~min}$, e colocado entre duas folhas de celofane, úmidas e tensionadas, por cerca de 48h. Os filmes obtidos dos géis foram digitalizados e analisados pelo software ImageJ $1.37 \mathrm{v}$, disponibilizado gratuitamente pelo U.S. National Institutes of Health na internet. A mobilidade relativa para cada amostra foi feita por comparação a um padrão conhecido de condroitin-4-sulfato, e é obtida pela razão entro o pico da curva de migração da amostra, dividido pelo pico da curva do CS4 no mesmo gel. Esse pico de migração representa a tendência central da distribuição de tamanho molecular da amostra. Quanto maior o valor da mobilidade relativa (MR), menor o peso molecular médio do GAG avaliado ${ }^{94}$. Os dados são expressos como a média \pm EPM da MR para cada grupo.

\section{Avaliação histopatológica}

As lâminas dos côndilos femorais foram avaliadas por dois patologistas cegos para os grupos de tratamento, conforme o recémpublicado escore da Sociedade Internacional de Pesquisa em Osteoartrite 
$(\mathrm{OARSI})^{60}$. Segundo esse sistema, grau (variando de 0 a 6) avalia a gravidade da lesão da cartilagem articular, enquanto estágio (variando de 1 a 4) avalia a extensão das lesões compatíveis com OA na articulação. grau é fornecido pela lesão mais grave observada na lâmina, independente da extensão dessa lesão. Já estágio é definido pela extensão horizontal do acometimento da cartilagem, independente da gravidade das lesões. Ao final, é fornecido um escore, que é calculado pela fórmula grauXestágio, o qual fornece uma avaliação combinada de gravidade e extensão do dano estrutural na articulação. O escore varia de 0 a 24. Para cada animal, foi fornecido um valor médio para grau, estágio e escore da articulação. Os dados são expressos como mediana (menor valor-maior valor) de cada grupo.

\section{Quantificação do NO no lavado articular}

A quantidade de NO no lavado articular nos animais sete dias após TLCA foi avaliada indiretamente pela medida da concentração total de nitrito $\left(\mathrm{NO}_{2}{ }^{-}\right)$e nitrato $\left(\mathrm{NO}_{3}{ }^{-}\right)$através da reação de Griess. O nitrato foi convertido a nitrito por incubação com a enzima nitrato redutase. Quarenta microlitros de cada amostra foram incubados com $40 \mu \mathrm{l}$ de nitrato redutase $(0,4 \mathrm{U} / \mathrm{ml})$ e 40 $\mu \mathrm{l}$ de NADPH $(1 \mathrm{mM})$ por 30 minutos a $37^{\circ} \mathrm{C}$. Após a incubação, $80 \mu \mathrm{l}$ do reagente de Griess (um volume de sulfanilamida 1\% em ácido fosfórico 5\%, para um volume de $\mathrm{N}$-(1-naftil)-etilenodiamina $0,1 \%$ ) foram adicionados, e a absorbância foi medida por espectrofotometria. A concentração de nitrito foi 
obtida por comparação da absorbância com a de soluções com concentrações conhecidas de nitrito $(1-100 \mu \mathrm{M})$. Os dados $(e m \mu \mathrm{M})$ são expressos como a média \pm EPM para cada grupo.

\section{Estatística}

Diferenças entre as médias foram comparadas usando Análise de Variância (ANOVA) seguida do teste de Tukey. Para comparação das medianas foi usado o teste de Mann-Whitney. O nível de significância adotado foi de $5 \%(p<0,05)$. 


\section{RESULTADOS}

\section{Efeito de Sulfato de Glicosamina e Sulfato de Glicosamina/Sulfato de condroitina sobre a incapacitação articular}

Os animais submetidos à TLCA apresentaram TSP significativamente maior do que o grupo SHAM nos primeiros 14 dias após a cirurgia. Contudo, após esse período e até o D70, não foi observado um aumento significativo e consistente do TSP (figura 1).

A administração profilática de GluChon teve efeito antinociceptivo, reduzindo significativamente a incapacitação articular (figura 2). O TSP foi reduzido em 18,5\% ( $p<0,01)$ nesses animais quando comparados aos animais que receberam apenas salina (OANT). O sulfato de glicosamina também reduziu o TSP (redução de 13,5\%), contudo não foi alcançada significância estatística. A magnitude da redução da incapacitação articular pela combinação GluChon foi comparável a obtida com a administração subcutânea do meloxicam (figura 2). 

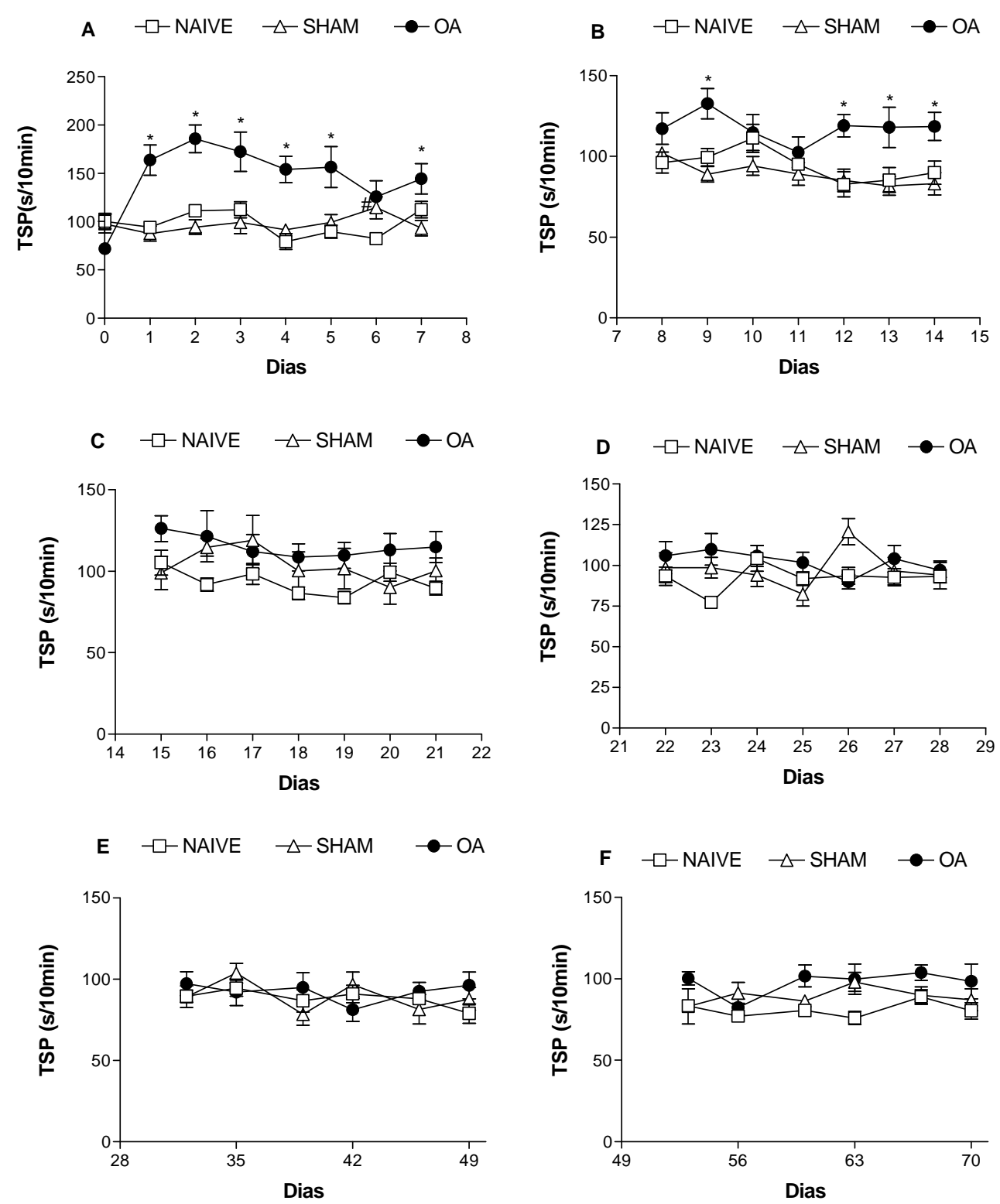

Figura 1- Cinética da incapacitação articular no modelo de OA por TLCA em ratos. A incapacitação articular foi avaliada pela medida do tempo de suspensão da pata (TSP). Os animais submetidos a TLCA (OA) apresentaram aumento do TSP nos primeiros 14 dias após a cirurgia. Após esse período não houve diferença entre os animais $O A$ e os falso-operados (sham) e não-operados (naive). ${ }^{*} p<0,05$ versus sham;" $p<0,05$ versus naive (animais não operados) (ANOVA seguida de Tukey). 


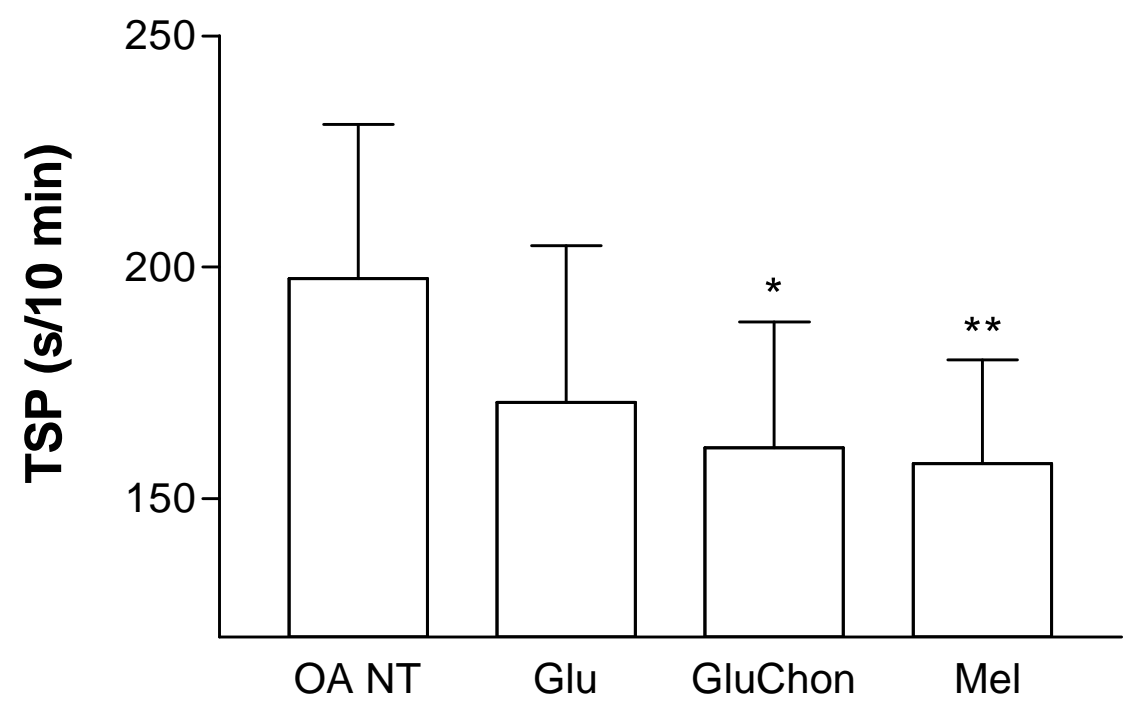

Figura 2- Efeito antinociceptivo de Sulfato de Glicosamina e Sulfato de Glicosamina / Sulfato de Condroitina em animais submetidos a TLCA. OANT - animais tratados com salina; Glu - animais tratados com sulfato de glicosamina; Gluchon - animais tratados com sulfato de glicosamina e sulfato de condroitina associados. Médias TSP (seg/10 $\mathrm{min}$ ): OANT: 197,5 $\pm 33,4$; Glu: 170,7 $\pm 33,9$; GluChon: 160,9 $\pm 27,2$; Mel: 157,5 $\pm 22,5$. Grupos de pelo menos 9 animais. ${ }^{*} p<0,01$ versus OANT; ${ }^{* *} p<0,001$ vs OANT (ANOVA seguida de Tukey). 


\section{Caracterização dos GAGs da cartilagem articular}

\section{Quantificação dos GAGs após eletroforese em gel de agarose}

O único GAG extraído da cartilagem articular dos animais foi o condroitin-sulfato, conforme ilustrado na figura 3. Setenta dias após a TLCA, a concentração de CS na cartilagem foi significativamente maior no grupo OA que no grupo sham (OA: $77,68 \pm 3,38 \mu \mathrm{g} / \mathrm{mg}$; SHAM: $53,46 \pm 4,58 \mu \mathrm{g} / \mathrm{mg}$, $p<0,001)$. Nos outros tempos de observação, não houve diferença na concentração do CS entre os grupos OA e Sham (figura 4).

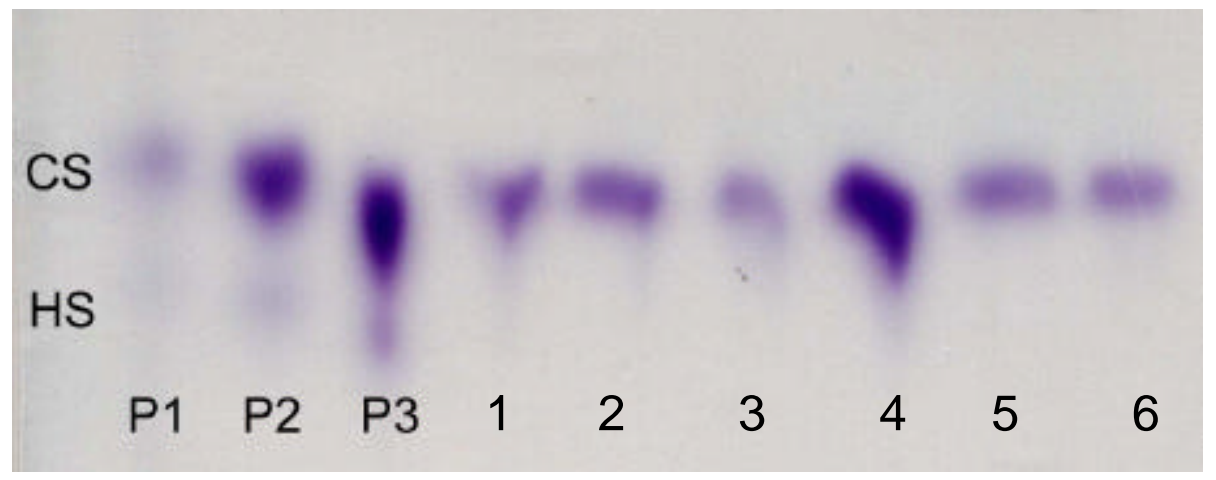

Figura 3- Eletroforese em gel de agarose dos GAGs da cartilagem articular de ratos $\mathrm{OA}$ - O único GAG presente nas amostras foi o condroitin sulfato. O tampão 1,3-diaminopropano-acetato $0,05 \mathrm{M}(\mathrm{pH} \mathrm{9,0)}$ discrimina as bandas dos condrotin-sulfatos 4 e 6 (CS), dermatan-sulfato e keratan-sulfato (não ilustrados) e heparan-sulfato (HS). P1: 1,0 $\mu \mathrm{g}$ de cada padrão (CS4, CS6 e HS); P2: 3,0 $\mu \mathrm{g}$ de cada padrão; P3: 4,5 $\mu \mathrm{g}$ de cada padrão; 1 a 6 amostras de animais SHAM. 


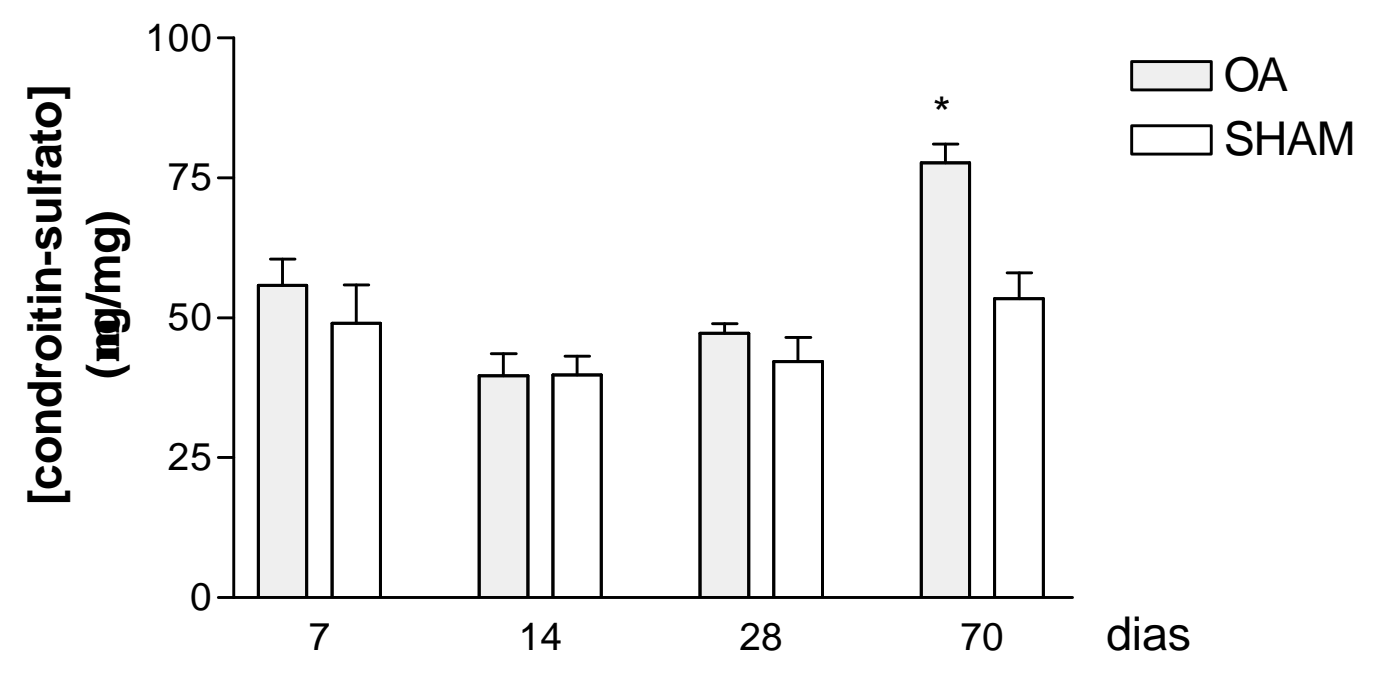

Figura 4 - Cinética da quantificação do CS extraído da cartilagem articular - os animais OA apresentaram uma elevação significativa da concentração de CS na cartilagem quando comparados aos animais SHAM após 70 dias. Tal elevação não foi vista nos outros tempos. Grupos de pelo menos 5 animais. ${ }^{*} p<0,001$ versus OA 70 dias (two way ANOVA)

Avaliação do peso molecular dos GAGs por eletroforese em gel de poliacrilamida

A eletroforese em gel de poliacrilamida do CS extraído das cartilagens mostrou um padrão de polidispersão, compatível com heterogeneidade de tamanho molecular das amostras. A mobilidade relativa (MR) do CS da cartilagem dos animais $\mathrm{OA}$ foi significativamente menor do que a MR dos animais SHAM (OA: 0,98 $\pm 0,02$; SHAM: $1,10 \pm 0,02, p<0,01)$, ou seja, o CS das cartilagens artrósicas apresenta um maior peso molecular que o dos animais SHAM. 
Efeito de Glu e GluChon sobre a lesão da cartilagem articular

\section{Efeito de Glu e GluChon sobre os GAGs da cartilagem articular}

O tratamento com GluChon restabeleceu as características dos GAGs dos animais OA, tanto prevenindo o aumento na concentração do CS extraído da cartilagem (figura 5), como restaurando o tamanho molecular desse CS (figura 7). O tratamento com Glu também tendeu a restabelecer a normalidade dos GAGs da cartilagem, associando-se a CS de peso molecular semelhante ao dos animais SHAM, porém sem prevenir de forma significativa o aumento da quantidade de CS. A figura 6 ilustra os géis de poliacrilamida para os diferentes grupos. 


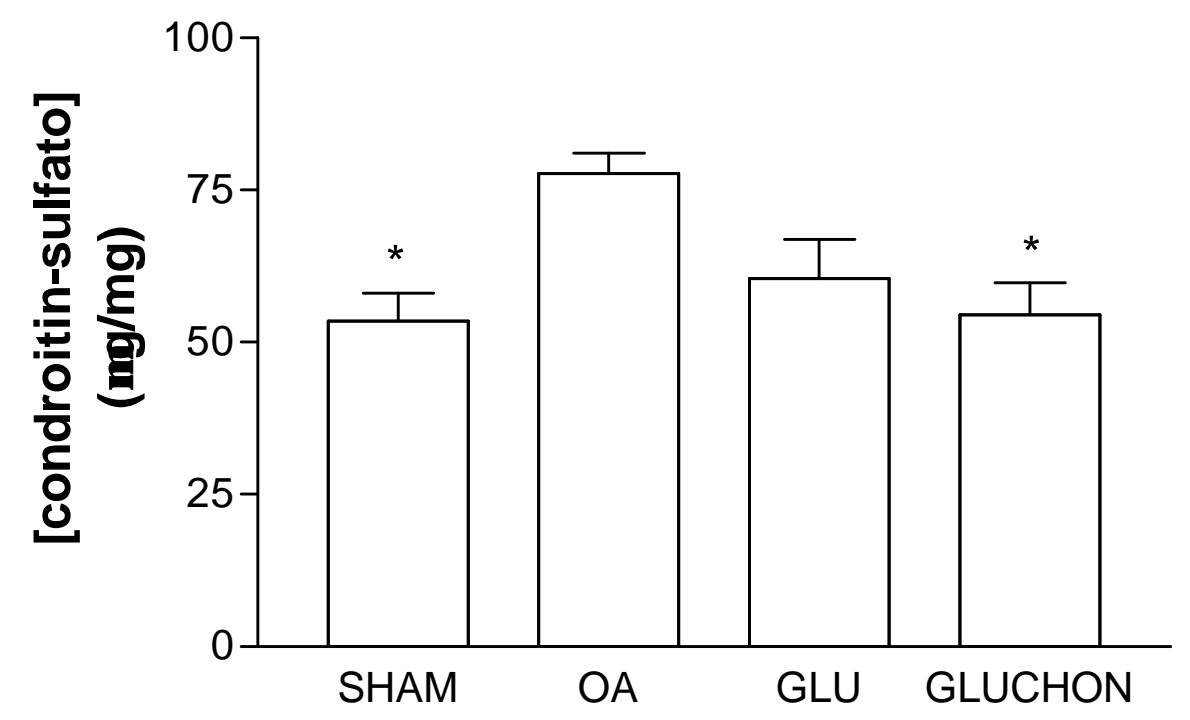

Figura 5 - Efeito de Sulfato de Glicosamina (Glu) e Sulfato de Glicosamina / Sulfato de Condroitina (GluChon) sobre a quantidade de GAG extraído da cartilagem de animais submetidos a TLCA - GluChon preveniu a elevação do CS da cartilagem nos animais submetidos a TLCA. Médias [CS] ( $\mu \mathrm{g}$ de CS / mg de cartilagem seca): OA: 77,68 $\pm 3,38$; SHAM: 53,46 $\pm 4,58$; Glu: 60,45 $\pm 6,50$; GluChon: 54,42 $\pm 5,39$ Grupos de pelo menos 5 animais. ${ }^{*} \mathrm{p}<0,05$ versus OA (ANOVA seguida de Tukey). 
A

C4S C6S

C

C4S C6S
B

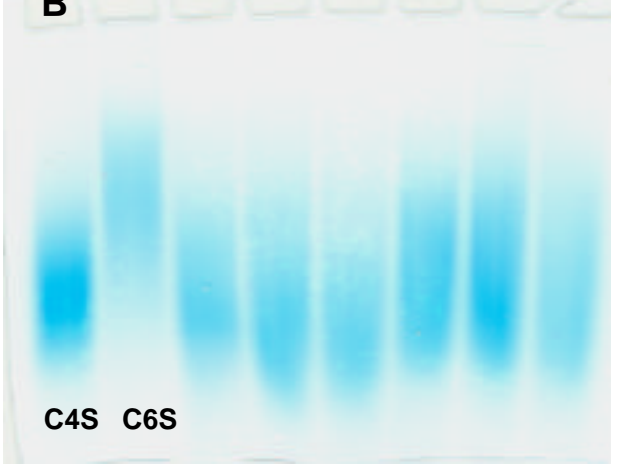

D

C4S C6S

Figura 6: Eletroforese em gel de poliacrilamida do condroitin-sulfato (CS) obtido da matriz da cartilagem femoral - observa-se um padrão de polidispersão compatível com a heterogeneidade de tamanho molecular do $\mathrm{CS}$ nas amostras. As massas molares ponderais dos padrões de condroitin4-sulfato (C4S) e condroitin-6-sulfato (C6S) são 4,55 x 105 $\mathrm{g} / \mathrm{mol}$ e $5,88 \times$ $10^{5} \mathrm{~g} / \mathrm{mol}$, respectivamente $\left(\mathrm{SIGMA}^{\circledR}\right)$. (A) Grupo $\mathrm{OA}$ não tratado 70 dias (OANT). (B) Grupo SHAM 70 dias (C) Grupo Glu 70 dias (D) Grupo GluChon 70 dias. 


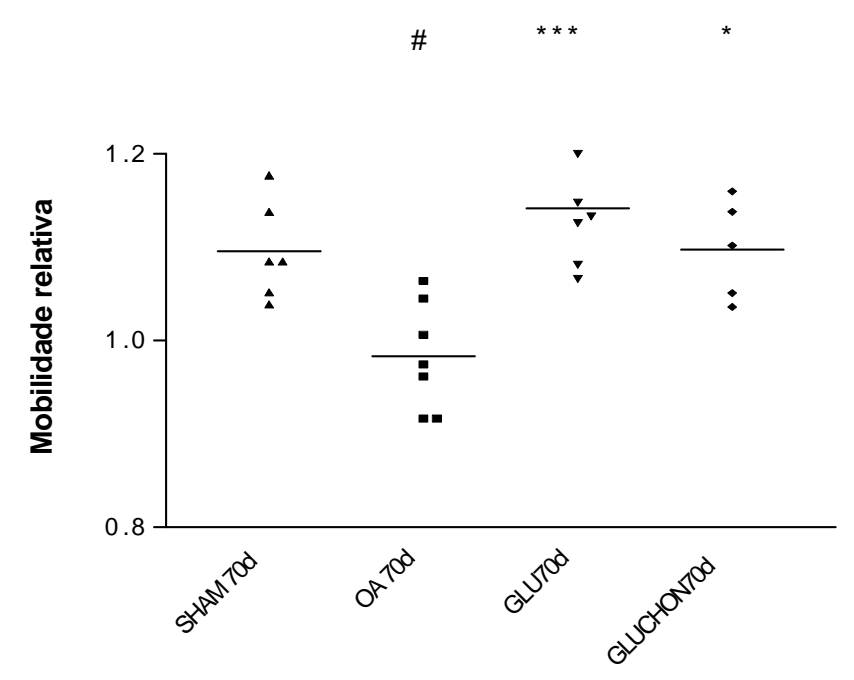

Figura 7 - Efeito de Sulfato de Glicosamina (Glu) e Sulfato de Glicosamina / Sulfato de Condroitina (GluChon) sobre o peso molecular do CS extraído da cartilagem - tanto Glu quanto GluChon preveniram o aumento do peso molecular associado a OA. Grupos de pelo menos 5 animais. ${ }^{\#} p<0,01$ vs SHAM, ${ }^{* *} p<0,001$ vs $O A ;{ }^{*} p<0,05$ vs OA (ANOVA seguida de Tukey).

\section{Efeito de Glu e GluChon sobre a lesão histopatológica}

A tabela 1 mostra os resultados da lesão articular observados nos vários grupos, utilizando o escore da OARSI. Observa-se que os animais submetidos a TLCA que receberam GluChon apresentaram significativamente menos dano na cartilagem que os animais OA tratados com salina. Foi evidenciada melhora tanto da gravidade como da extensão das lesões. Os animais que receberam Glu isoladamente também apresentaram uma redução do dano da cartilagem, mas os resultados não 
alcançaram significância estatística. A taxa de concordância entre os dois patologistas foi de 95\%, com índice kappa de 0,80.

A figura 8 ilustra micrografias da cartilagem articular, coradas por H\&E, de animais SHAM e submetidos à TLCA, e sacrificados após 70 dias. Nos grupos tratados com sulfato de glicosamina, associado ou não ao sulfato de condroitina, é possível observar o aspecto íntegro da superfície articular quando comparado ao grupo que recebeu apenas salina. A figura 9 ilustra os mesmos aspectos, agora com a coloração por azul de toluidina. A figura 10 mostra imagens com maior aumento, observando-se intensa coloração por azul de toluidina, indicativa da preservação dos proteoglicanos da matriz extracelular, nos grupos tratados com sulfato de glicosamina isolado ou associado ao sulfato de condroitina, quando comparados aos grupos OA NT.

Tabela 1: Efeito de Sulfato de Glicosamina (Glu) e Sulfato de Glicosamina / Sulfato de Condroitina (GluChon) sobre a lesão histológica da cartilagem articular

\begin{tabular}{lccc|}
\hline & OANT & Glu & GluChon \\
\hline Grau & $4(4-5)$ & $4(2-6)$ & $2(1-2)^{*}$ \\
Estágio & $3,5(2-4)$ & $1(1-2)$ & $1(0-2)^{*}$ \\
Escore & $14(8-20)$ & $4(2-12)$ & $2(0-2)^{*}$ \\
\hline \multicolumn{2}{l}{ Valores : mediana (menor valor-maior valor). ${ }^{*} \mathrm{p}<0,05$ vs OANT (Mann-Witney) }
\end{tabular}



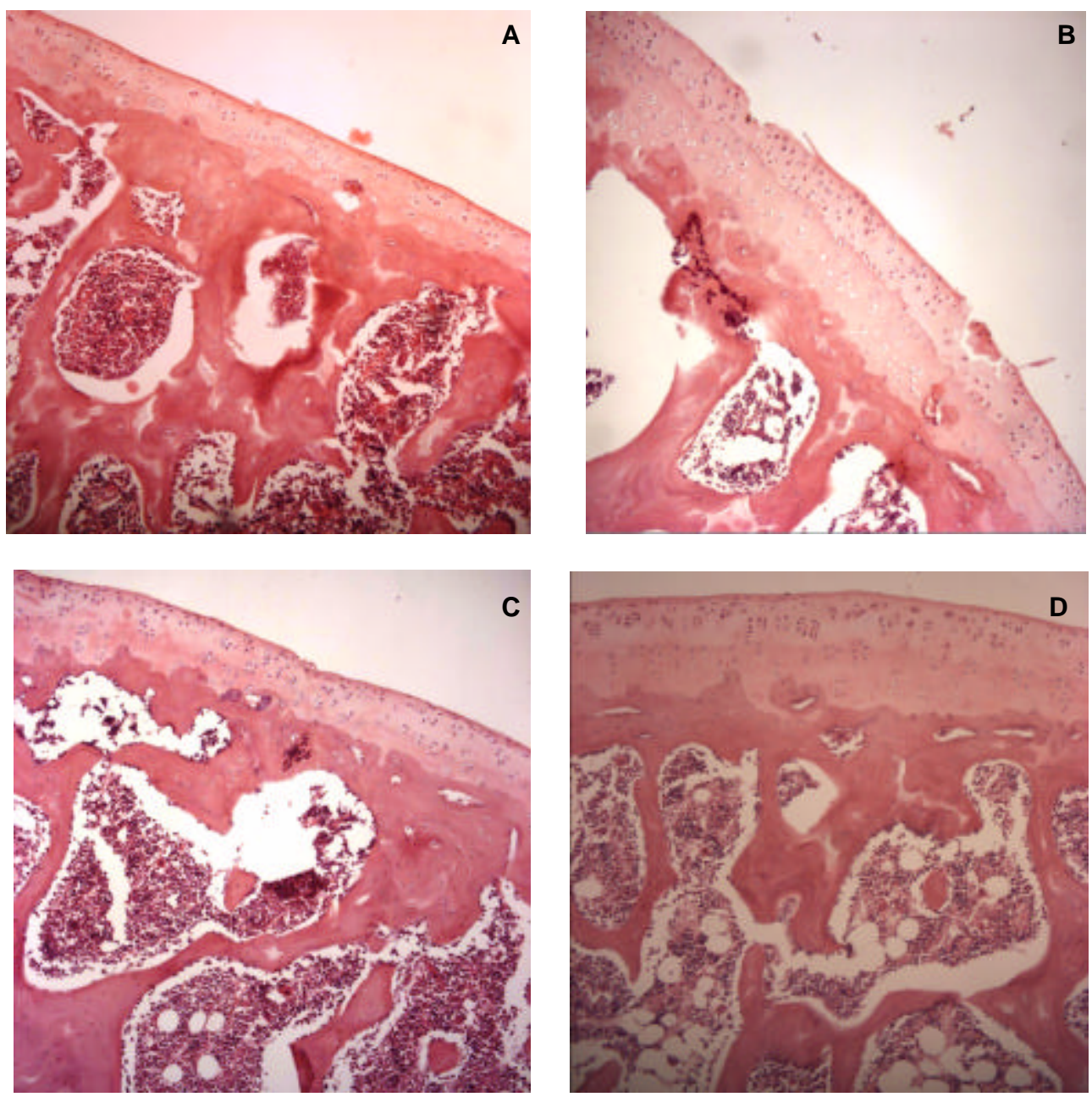

Figura 8: Fotomicrografias de cartilagens dos animais de $\mathbf{7 0}$ dias $(A)$ SHAM. (B) OA não tratado (recebeu salina). (C) Tratado com Sulfato de Glicosamina. (D) Tratado com Sulfato de Glicosamina / Sulfato de Condroitina. Coloração: H\&E. Aumento de 100x. 

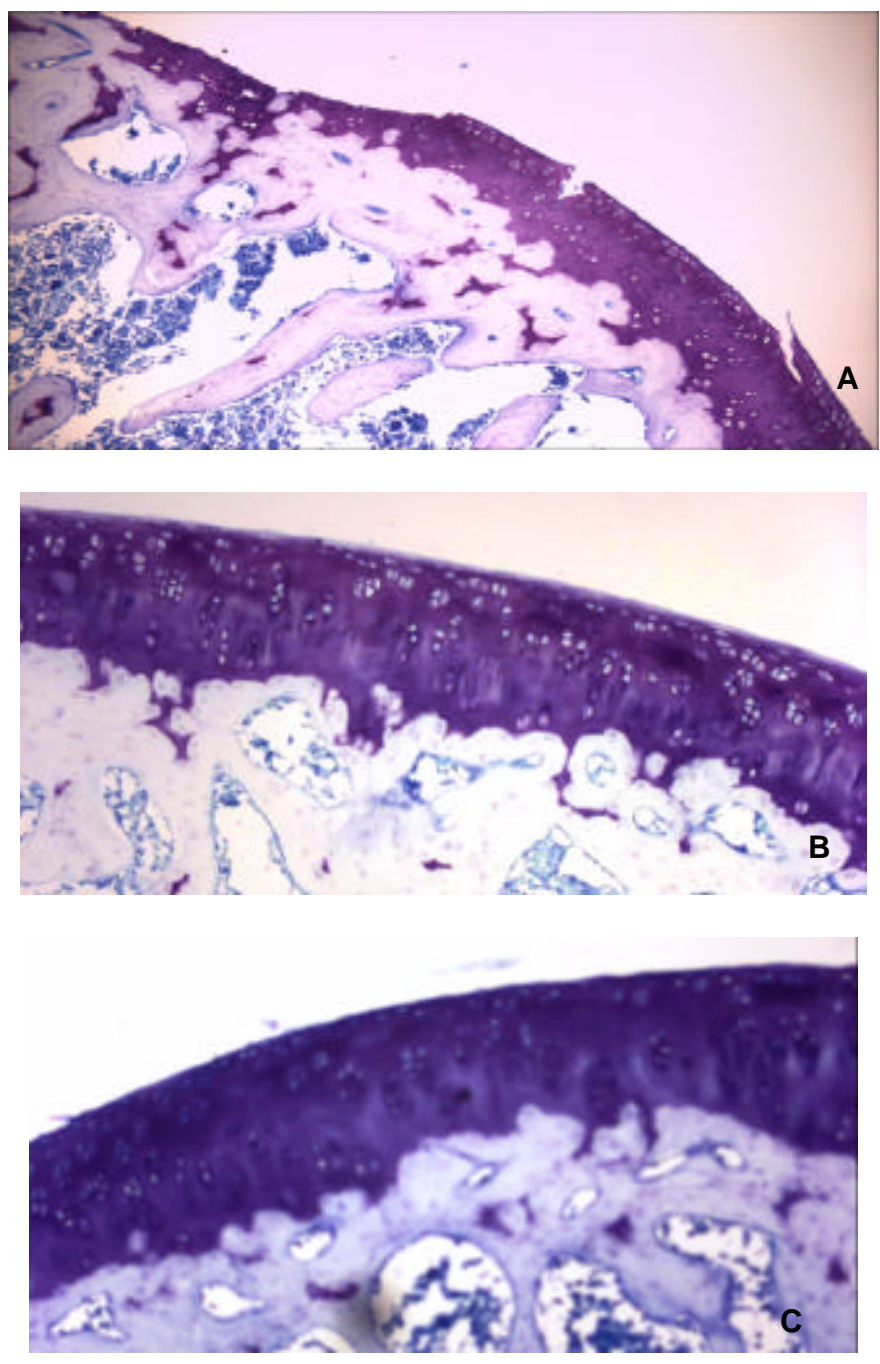

Figura 9: Fotomicrografias de cartilagens dos animais de $\mathbf{7 0}$ dias. (A) $O A$ não tratado (salina). (B) Tratado com Sulfato de Glicosamina. (C) Tratado com Sulfato de Glicosamina / Sulfato de Condroitina. Coloração: azul de toluidina. Aumento de 100X. 

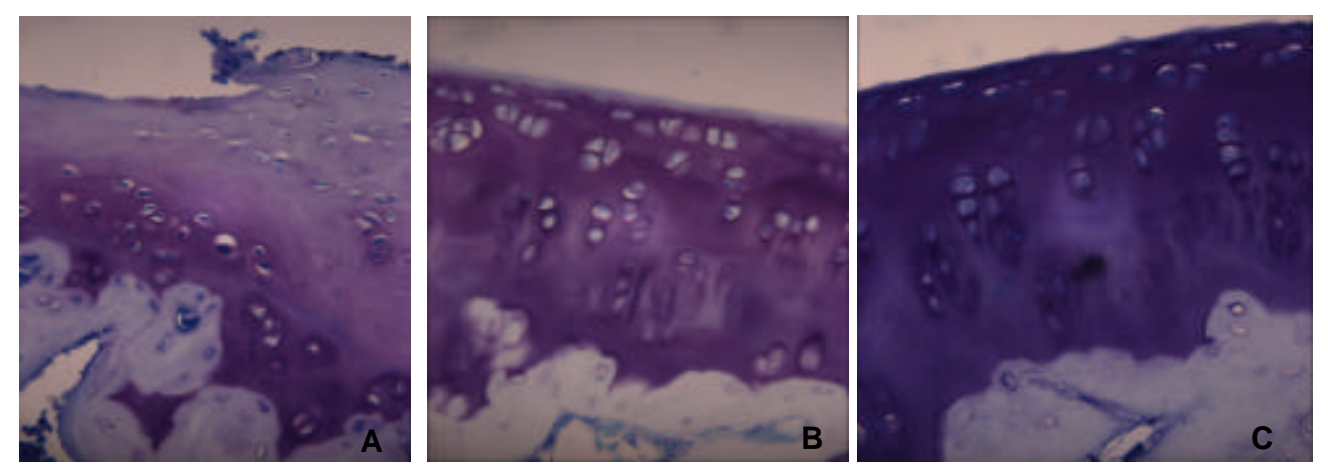

Figura 10: Fotomicrografias de cartilagens dos animais de $\mathbf{7 0}$ dias. (A) $\mathrm{OA}$ não tratado (salina). (B) Tratado com Sulfato de Glicosamina. (C) Tratado com Sulfato de Glicosamina / Sulfato de Condroitina. Coloração: azul de toluidina. Aumento de 400X.

\section{Efeito de Glu e GluChon sobre a liberação de NO na cavidade articular}

O tratamento com Glu associou-se a um aumento significativo do NO no lavado articular (figura 11). GluChon também associou-se a aumento do NO no lavado articular, mas não foi alcançada significância estatística. 


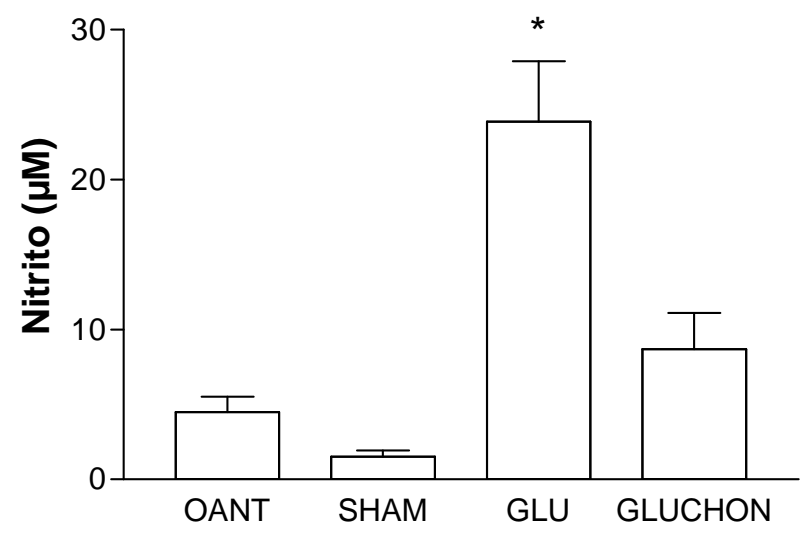

Figura 11- Efeito de Glu e GluChon sobre a liberação de NO no lavado articular. Glu associou-se a importante aumento da quantidade total de $\mathrm{NO}_{2}{ }^{-} / \mathrm{NO}_{3}$ na cavidade articular, enquanto o aumento associado a GluChon foi moderado. ${ }^{*} p<0,001$ vs OANT (ANOVA seguida de Tukey). 


\section{DISCUSSÃO}

Os mecanismos envolvidos na gênese da dor na OA são pouco compreendidos. Um esforço significativo tem sido feito no sentido de caracterizar modelos animais que mimetizem a doença humana. Contudo, só recentemente foram padronizados métodos de avaliação de dor em modelos experimentais de $O A^{88}$. Nosso grupo padronizou um método quantitativo objetivo para avaliação de hipernocicepção em ratos submetidos

à TLCA ${ }^{22}$. Enquanto os outros modelos descritos até o momento avaliam a distribuição estática do peso corporal entre as patas traseiras dos animais como medida de um comportamento associado a hipernocicepção ${ }^{95-99}$, o método desenvolvido em nosso laboratório é singular por avaliar a dor associada à deambulação, assemelhando-se mais ao padrão de dor encontrado na doença humana. Uma vez que havíamos observado que os animais só apresentavam incapacitação articular nos primeiros 14 dias após indução da OA, o presente trabalho estendeu o período de avaliação até 70 dias.

Observamos que os animais do grupo OA não apresentaram um padrão consistente de dor articular avaliada por este método após as duas primeiras semanas de TLCA. O teste de incapacitação articular avalia se o animal toca ou não no cilindro metálico, e não a quantidade de força aplicada pela pata ao solo. Sabe-se que animais submetidos à TLCA desenvolvem mecanismos de adaptação da marcha no sentido de poupar a 
pata afetada durante a deambulação. Esse tipo de adaptação pode ser grosseiramente comparado ao uso de uma bengala pelos pacientes com OA. Dados de estudos em cães submetidos à TLCA mostraram uma redução da fase estacionária da marcha ${ }^{100}$, enquanto em gatos submetidos à TLCA, a hipertrofia e fibrose da cápsula articular reduzem a translação tibial anterior, dessa forma aliviando alterações da marcha associadas a dor articular 101,102. Podemos especular que esse tipo de adaptação possa ocorrer também nos ratos submetidos à TLCA, explicando a flutuação e irregularidade da medida do TSP observada após 14 dias, impedindo assim uma avaliação mais prolongada da dor. O grupo está trabalhando no sentido de tentar resolver essa limitação.

A eficácia sintomática de sulfato de glicosamina e sulfato de condroitina é controversa ${ }^{20}$. A redução de dor associada a esses compostos tem sido mais atribuída a suas possíveis propriedades modificadoras de doença do que a um efeito analgésico direto. O sulfato de glicosamina, em doses de até $500 \mathrm{mg} / \mathrm{kg}$, não apresentou efeito antinociceptivo no modelo de contorção abdominal em camundongos ${ }^{103}$. Contudo, a combinação de sulfato de glicosamina com alguns analgésicos não opióides resultou em sinergismo (ibuprofeno e cetoprofeno), efeito aditivo (diclofenaco, indometacina, naproxeno e piroxicam) ou subaditivo (aspirina e acetoaminofeno $)^{103}$, o que sugere propriedades analgésicas intrínsecas leves. Ainda, a aplicação tópica de um creme contendo glicosamina e condroitina reduziu a dor em pacientes com OA de joelhos ${ }^{104}$, o que também 
sugere propriedades analgésicas intrínsecas desses compostos, independente de um efeito estrutural.

O presente trabalho é a primeira demonstração de que a combinação de sulfato de glicosamina e sulfato de condroitina reduz a hipernocicepção em um modelo experimental de OA. O TSP foi reduzido em $18,5 \%$ nos animais $O A$ que receberam GluChon. Como comparação, demonstramos que a magnitude do efeito antinociceptivo obtido foi semelhante ao meloxicam, um inibidor da ciclooxigenase, que foi utilizado como controle positivo do experimento. O sulfato de glicosamina isoladamente também reduziu a dor (redução de $13,5 \%$ do TSP), porém em menor proporção do que a combinação, sem alcançar significância estatística. Apesar de não podermos excluir totalmente um efeito analgésico do sulfato de condroitina, nossos dados sugerem que os dois compostos atuam sinergicamente para redução da dor.

O modelo de TLCA propicia a avaliação de dor numa fase precoce da OA. Apesar de os ratos já apresentarem alterações estruturais compatíveis com OA tão cedo quanto sete dias após a TLCA ${ }^{21}$, é provável que a redução da hipernocicepção observada com os compostos não guarde correlação com modificação estrutural, mas sim com alterações em mecanismos sutis de mediação bioquímica da dor. Numa tentativa de esclarecer o possível mecanismo antinociceptivo dos compostos, foi realizada a quantificação de $\mathrm{NO}_{2}^{-} / \mathrm{NO}_{3}^{-}$no líquido articular coletado no sétimo dia pós-TLCA. Demonstramos pela primeira vez em um modelo in vivo, que a administração 
oral de sulfato de glicosamina e sulfato de condroitina modula a liberação de NO na cavidade articular.

O papel do NO na nocicepção é controverso. Nosso grupo, trabalhando com o modelo de artrite induzida por zymosan em ratos, demonstrou que a administração sistêmica ou local de inibidores da NOS produz antinocicepção apenas quando feita profilaticamente, mas não quando realizada após a indução da artrite ${ }^{105}$. Por outro lado, a administração terapêutica de doadores exógenos de NO foi associada à antinocicepção, caracterizando um efeito dual do NO nesse modelo ${ }^{105}$. No modelo de TLCA, a administração profilática, mas não terapêutica de inibidores da NOS, reduziu a dor articular ${ }^{22}$. Enquanto a administração de inibidores da NO sintase (NOS), como o L-NAME, foi associada à antinocicepção em vários modelos experimentais ${ }^{106}$, a administração de doadores exógenos do NO, como o SIN-1, tem sido associada tanto a hiper quanto a antinocicepção ${ }^{107,108}$. Podemos especular que o aumento moderado do NO na cavidade articular observado com os tratamentos no presente estudo está associado à antinocicepção observada nos animais tratados.

Nossos achados se contrapõem a estudos que imputam ao sulfato de glicosamina e ao sulfato de condroitina a propriedade de inibir a síntese e liberação de NO. O sulfato de glicosamina reduziu significativamente a expressão do RNAm da iNOS induzida pela IL-1ß em cultura de condrócitos eqüinos $^{109}$. Tanto glicosamina quanto $\mathrm{N}$-acetilglicosamina inibiram a produção de NO e a expressão da iNOS induzida por IL-1ß e TNF-a em 
condrócitos humanos normais ${ }^{110}$. A administração sistêmica de glicosamina reduziu tanto a excreção urinária de nitrito em ratos submetidos a peritonite por LPS ${ }^{111}$, quanto os níveis de NO sérico no modelo de artrite por adjuvante em ratos ${ }^{112}$. O sulfato de condroitina também parece afetar a produção de NO. Apesar de a expressão do RNAm da iNOS induzida por IL-1ß em cultura de condrócitos eqüinos não ter sido alterada pelo sulfato de condroitina $^{109}$, a combinação de sulfato de glicosamina e condroitina reduziu a expressão da iNOS induzida por IL-1 em condrócitos bovinos ${ }^{84}$. Ainda que nossos resultados aparentemente contradigam as evidências da literatura, nenhum estudo havia ainda avaliado o efeito desses compostos na liberação de NO diretamente na cavidade articular em modelos in vivo. O grupo está trabalhando no sentido de confirmar e caracterizar o significado desses achados.

Mesmo que os resultados obtidos em modelos animais representem apenas hipóteses a serem testadas em estudos clínicos, podem ajudar a esclarecer controvérsias em relação a tratamentos e drogas, e nesse sentido os resultados de melhora estrutural obtidos no presente trabalho fornecem evidência de benefício do sulfato de glicosamina e de sua combinação com sulfato de condroitina na OA. A avaliação da lesão da cartilagem articular em modelos experimentais tem sido tradicionalmente baseada no escore descrito por Mankin ${ }^{113}$. Contudo, a reprodutibilidade e validade desse escore têm sido questionadas ${ }^{114,115}$, o que levou a OARSI a desenvolver um novo sistema para padronizar a avaliação histopatológica em estudos em $O A^{60}$. Esse sistema é mais simples de usar e permite uma avaliação mais 
detalhada dos achados compatíveis com $O A$ na cartilagem ${ }^{60}$. A utilização desse escore por dois patologistas experientes, um deles patologista veterinário, cegos para os grupos de tratamento, foi associada a uma alta taxa de concordância inter-observador no presente trabalho.

Ainda que controverso, tem sido sugerido que diferentes formulações de glicosamina, em particular o sulfato de glicosamina e o cloridrato de glicosamina, apresentem eficácia diferente na $O A^{20,77}$. Os estudos em modelos experimentais realizados até o momento utilizaram cloridrato de glicosamina, e não conseguiram demonstrar um claro benefício desse composto sobre a lesão da cartilagem articular ${ }^{86,87,116}$. O presente trabalho é o primeiro a utilizar o sulfato de glicosamina, e ainda que os dados histológicos semi-quantitativos não tenham alcançado significância estatística, houve melhora histopatológica nos animais tratados. Nossos dados acrescentam aos de um estudo prévio em coelhos em que a associação de cloridrato de glicosamina e sulfato de condroitina foi mais eficaz do que as drogas isoladamente ${ }^{87}$, sugerindo um maior benefício do uso associado dos compostos quando comparado ao seu uso isolado.

Ainda que histologia seja considerada o padrão-ouro na avaliação do dano da cartilagem articular na $O A$, fornece dados não-paramétricos e passíveis de influência subjetiva por parte do observador. No sentido de tentar estabelecer um critério mais objetivo, gerando dados paramétricos e observador-independente, avaliamos a quantidade e o peso molecular das cadeias de glicosaminoglicanos extraídos da cartilagem articular. 
Os dados obtidos em amostras de cartilagem de animais 70 dias após a TLCA mostraram um aumento do condroitin-sulfato (expresso em mg / peso de cartilagem seca) extraído do grupo OA em comparação aos animais falso-operados (SHAM). Essa elevação do CS não foi encontrada nas fases mais precoces da $\mathrm{OA}$ no modelo. Aumento na concentração de proteoglicanos e glicosaminoglicanos na matriz extracelular da cartilagem tem sido descrito nas fases iniciais da $O A$, e reflete provavelmente uma tentativa de reparo da lesão tecidual pelos condrócitos ${ }^{117}$. Nas fases mais avançadas, as concentrações de PG e GAGs caem significativamente, mesmo num contexto de neosíntese pelos condrócitos, refletindo mecanismos de catabolismo ainda mais intensos ${ }^{117}$. Esperávamos, a princípio, que a progressão da OA nos ratos submetidos à TLCA evoluísse com redução da concentração de CS na cartilagem, em particular na fase crônica, dez semanas após a cirurgia, onde os achados compatíveis com OA já são bem evidentes. Contudo, esse achado de elevação de GAGs tem sido descrito mesmo em fases avançadas em modelos experimentais de OA. No modelo de TLCA em cães, por exemplo, um aumento na quantidade de GAGs foi mantido até 64 semanas após a indução da $O A^{118,119}$.

Foi feita então a hipótese de que a "qualidade" desses GAGs recémsintetizados seria inadequada, o que nos levou a avaliar o padrão de distribuição do peso molecular do CS nas amostras através de eletroforese em gel de poliacrilamida. Os dados obtidos sustentam a hipótese formulada. De fato, a análise do CS por esse método mostrou que a elevação de sua concentração ocorreu às custas de moléculas de maior tamanho. Esse 
achado está em concordância com os dados de um trabalho apresentado no último congresso da OARSI, em $2006^{120}$, onde um aumento do tamanho da cadeia de CS foi observado no líquido sinovial de cavalos com lesão osteocondral associada a corridas. Entretanto, em cartilagens humanas de joelhos OA obtidas em autópsia, observou-se uma redução significativa do tamanho do CS, consistente com despolimerização da molécula ${ }^{121}$. Já na OA associada a displasia de quadril em cães ${ }^{122}$, bem como em espécimes de cartilagem de pacientes com $O A$ de quadril ${ }^{123}$, não foram encontradas diferenças no tamanho molecular do CS.

Apesar do significado fisiopatológico desses achados não estar claro, esse aumento na concentração e tamanho molecular do CS está associado à progressão da OA no modelo por TLCA em ratos, e isso foi demonstrado pelo efeito obtido com sulfato de glicosamina e sulfato de glicosamina / sulfato de condroitina nos grupos tratados. Esses compostos, em particular a associação (GluChon), reduziram tanto a gravidade quanto a extensão da lesão histológica da cartilagem articular, e essa condroproteção foi acompanhada de alteração do perfil dos GAGs extraídos da cartilagem, aproximando esse perfil daquele encontrado nos animais SHAM.

Em outras palavras, a prevenção do aumento da concentração e do tamanho molecular do CS associados à OA nesse modelo, protege da lesão da cartilagem articular. Esses achados sugerem que a tentativa desorganizada de reparo da lesão da matriz extracelular da cartilagem articular possa, ao invés de impedir, contribuir para a progressão da doença, e que terapêuticas que "normalizem" essa resposta anabólica possam 
reduzir a progressão da lesão estrutural na OA. Uma vez que o CS é o GAG mais abundante na cartilagem articular, e o principal responsável pela pressão de hidratação do tecido, essa alteração quantitativa e qualitativa pode responder pela hidratação observada na cartilagem artrósica nas fases iniciais da doença, e contribuir para desestabilização das propriedades mecânicas do tecido, promovendo progressão da lesão.

Uma das formas de validar um modelo experimental de uma doença é demonstrar que intervenções efetivas na doença humana são eficazes no modelo em questão. Ainda que haja bastante controvérsia em relação a eficácia sintomática e estrutural de sulfato de glicosamina e sulfato de condroitina, esses compostos estão entre os candidatos a DMOAs mais estudados em humanos, existindo considerável evidência de que reduzam dano estrutural e apresentem efeito sintomático. A demonstração de que essas drogas apresentam esse mesmo tipo de efeito no modelo de TLCA em ratos contribui para a validação desse modelo. 


\section{CONCLUSÕES}

1. A associação sulfato de glicosamina e sulfato de condroitina reduz a dor articular no modelo de osteoartrite induzida por transecção do ligamento cruzado anterior em ratos. Sulfato de glicosamina também apresentou uma tendência para redução da incapacitação articular, porém não foi alcançada significância estatística.

2. A progressão da lesão da cartilagem articular foi associada a um aumento da concentração e do tamanho molecular do condroitin-sulfato extraído da cartilagem articular.

3. O tratamento dos animais com a combinação de sulfato de glicosamina e sulfato de condroitina preveniu tanto o aumento da concentração quanto o aumento do tamanho molecular do condroitin-sulfato extraído da cartilagem articular, e esses efeitos foram associados a melhora da lesão histopatológica da cartilagem. Sulfato de glicosamina isoladamente também mostrou uma tendência para prevenção das alterações do condroitin-sulfato e redução da lesão histológica da cartilagem, porém os resultados não alcançaram significância estatística. 
4. A caracterização dos glicosaminoglicanos da cartilagem articular pode servir como um índice de lesão para avaliação de drogas condroprotetoras no modelo de osteoartrite por transecção do ligamento cruzado anterior em ratos.

5. A associação sulfato de glicosamina e sulfato de condroitina é mais eficaz do que sulfato de glicosamina isoladamente tanto para redução da incapacitação articular quanto para redução da lesão da cartilagem articular nesse modelo.

6.O modelo de osteoartrite por transecção do ligamento cruzado anterior em ratos é útil para avaliação de drogas modificadoras de doença na OA. 


\section{REFERÊNCIAS}

1. Attur MG, Dave M, Akamatsu M, Katoh M, Amin AR. Osteoarthritis or osteoarthrosis: the definition of inflammation becomes a semantic issue in the genomic era of molecular medicine. Osteoarthritis Cartilage. 2002; 10:1-4.

2. Sharma L, Kapoor D, Issa S. Epidemiology of osteoarthritis: an update. Curr Opin Rheumatol. 2006; 18:147-56.

3. Brooks PM. Impact of osteoarthritis on individuals and society: how much disability? Social consequences and health economic implications. Curr Opin Rheumatol. 2002;14:573-7.

4. Lawrence RC, Helmick CG, Arnett FC, Deyo RA, Felson DT, Giannini $\mathrm{EH}$, et al. Estimates of the prevalence of arthritis and selected musculoskeletal disorders in the United States. Arthritis Rheum 1998; 41:778-99.

5. Bocato R. Artrose é a maior causa de afastamentos. Folha de São Paulo, São Paulo. 2005 dez 18.

6. World Health Organization and the Bone and Joint Decade, 2001. Disponível em: http://www.boneandjointdecade.org.

7. Dieppe $\mathrm{P}$, Cushnaghan J, Tucker M, Browning S, Shepstone L. The Bristol 'OA500 study': progression and impact of the disease after 8 years. Osteoarthritis Cartilage. 2000; 8:63-8. 
8. Peters TJ, Sanders C, Dieppe P, Donovan J. Factors associated with change in pain and disability over time: a community-based prospective observational study of hip and knee osteoarthritis. $\mathrm{Br} J$ Gen Pract 2005; 55:205-11.

9. Lane NE, Nevitt MC, Hochberg MC, Hung YY, Palermo L. Progression of radiographic hip osteoarthritis over eight years in a community sample of elderly white women. Arthritis Rheum 2004; 50:1477-86.

10. Creamer P. Current perspectives on the clinical presentation of joint pain in human OA. Novartis Found Symp 2004; 260: 64-78.

11. Bruyere O, Honore A, Ethgen O, Rovati LC, Giacovelli G, Henrotin YE, Seidel L, Reginster JY. Correlation between radiographic severity of knee osteoarthritis and future disease progression. Results from a 3year prospective, placebo-controlled study evaluating the effect of glucosamine sulfate. Osteoarthritis Cartilage. 2003;11(1):1-5.

12. Brandt KD. Non-surgical treatment of osteoarthritis: a half century of "advances". Ann Rheum Dis. 2004; 63(2):117-22.

13. Towheed TE, Maxwell L, Judd MG, Cotton M, Hochberg MC, Wells G. Acetaminophen for osteoarthritis. Cochrane Database Syst Rev 2006; 1:CD 004257

14. Cepeda MS, Camargo F, Zea C, Valencia L. Tramadol for osteoarthritis. Cochrane Database Syst Rev 2006; 3:CD 005522.

15. Dieppe P. Disease modification in osteoarthritis: are drugs the answer? Arthritis Rheum 2005; 52:1956-9. 
16. Reginster JY, Deroisy R, Rovati LC, Lee RL, Lejeune E, Bruyere O, et al. Long-terms effects of glucosamine sulphate on osteoarthritis progression: a randomized, placebo-controlled clinical trial. Lancet $2001 ; 357: 251-6$.

17. Pavelka K, Gatterova J, Olejarova M, Machacek S, Giacovelli C, Rovatti LC. Glucosamine sulphate use and delay of progression of knee osteoarthritis. Arch Intern Med 2002; 162: 2113-23.

18. Michel BA, Stucki G, Frey D, De Vathaire F, Vignon E, Bruehlmann P, Uebelhart D. Chondroitins 4 and 6 in osteoarthritis of the knee: a randomized, controlled trial. Arthritis Rheum 2005; 52:779-86.

19. Altman RD. Measurement of structure (disease) modification in osteoarthritis. Osteoarthritis Cartilage 2004; Suppl A:S69-76.

20. Hochberg MC. Nutritional supplements for knee osteoarthritis - still no resolution. N Engl J Med 2006; 354:858-60.

21. Stoop R, Buma P, van der Kraan PM, Hollander AP, Bilinghurst RC, Meijers THM, et al. Type II collagen degradation in articular cartilage fibrillation after anterior cruciate ligament transection in rats. Osteoarthritis Cartilage 2001; 9:308-15.

22. Castro RR, Cunha FQ, Silva Jr FS, Rocha FAC. A quantitative approach to measure joint pain in experimental osteoarthritis evidence for a role for nitric oxide. Osteoarthritis Cartilage 2006; 14: 769-76.

23. Bezerra MM, Brain SD, Greenacre S, Jeronimo SMB, Melo LB, Keeble J, Rocha FAC. Reactive nitrogen species scavenging rather than nitric 
oxide inhibition protects from articular cartilage damage in rat zymosan-induced arthritis. Br J Pharmacol 2004; 141:172-82.

24. Silva Jr FS, Rocha FAC. Zymosan induced arthritis in rats mechanisms involved in hypernociception and cartilage lysis. Acta Reumatol Port 2006; 31:143-9.

25. Pelletier JP, Martel-Pelletier J, Abramson SB. Osteoarthritis, an inflammatory disease: potential implications for the selection of new therapeutic targets. Arthritis Rheum 2001; 44: 1237-47.

26. Martel-Pelletier J. Pathophysiology of osteoarthritis. Osteoarthritis Cartilage 2004; 12:S31-33.

27. Di Cesare PE, Abramson SB. Pathogenesis of osteoarthritis. In: Harris Jr ED, Budd RC, Genovese MC, Firenstein GS, Sargent JS, Sledge CB, editors. Kelley's Textbook of Rheumatology, $7^{\mathrm{a} e d}$. Philadelphia: WB Saunders Co, 2005.

28. Kraus VB. Pathogenesis and treatment of osteoarthritis. Rheum Dis Clin North Am 1997; 81: 85-112.

29. Caron JP, Fernandes JC, Martel-Pelletier J, Tardif G, Mineau F, Geng C, Pelletier JP. Chondroprotective effect of intraarticular injections of interleukin-1 receptor antagonist in experimental osteoarthritis. Suppression of colagenase-1 expression. Arthritis Rheum 1996; 39: $1535-44$

30. Chevalier X, Girardeau B, Conrozier T, Marliere J, Kiefer P, Goupille P. Safety of intraarticular injection of interleukin-1 receptor antagonist 
in patients with painful knee osteoarthritis: a multicenter study. $J$ Rheumatol 2005; 32:1317-23.

31. Grunke M, Schulze-Koops H. Successful treatment of inflammatory knee osteoarthritis with tumor necrosis factor blockage. Ann Rheum Dis 2006; 65:555-6.

32. Laufer S. Role of eicosanoids in structural degradation in osteoarthritis. Curr Opin Rheumatol 2003; 15: 623-7.

33. He W, Pelletier JP, Martel-Pelletier J, Laufer S, Di Batista JA. Synthesis of interleukin 1beta, tumor necrosis factor-alpha, and interstitial collagenase (MMP-1) is eicosanoid dependent in human osteoarthritis synovial membrane explants: interactions with antiinflammatory cytokines. J Rheumatol 2002; 29: 546-53.

34. Moreau M, Boileau C, Martel-Pelletier J, Brunet J, Laufer S, Pelletier JP. Licofelone reduces progression of structural changes in a canine model of osteoarthritis under curative conditions: effect on protease expression and activity. J Rheumatol 2006; 33:1176-83.

35. Farrell AJ, Blake DR, Palmer RMJ, Moncada S. Increased concentrations of nitrite in synovial fluid and serum samples suggest increased nitric oxide synthesis in rheumatic diseases. Ann Rheum Dis 1992; 51:1219-22.

36. Pelletier JP, Jovanovic D, Fernandes JC, Manning P, Connor JR, Currie MG, et al. Reduced progression of experimental osteoarthritis in vivo by selective inhibition of inducible nitric oxide synthase. Arthritis Rheum 1998; 41: 1275-86. 
37. Davis M, Ettinger W, Neuhaus JM, Barclay JD, Degal MR. Correlates of knee pain among US adults with and without radiographic knee osteoarthritis. J Rheumatol. 2002; 19:1943-49.

38. Dieppe PA, Lohmander LS. Pathogenesis and management of pain in osteoarthritis. Lancet 2005; 365: 965-73.

39. Dougados M, Nguyen M, Berdah L, Mazieres B, Vignon E, Lequesne M, for the ECHODIAH Investigators Study Group. Evaluation of structure-modifying effects of diacerein in hip osteoarthritis: ECHODIAH, a three-year, placebo-controlled trial. Arthritis Rheum $2001 ; 44: 2539-47$

40. Brandt KD, Mazzuca SA, Katz BP, Lane KA, Buckwalter KA, Yocum $D E$, et al. Effects of doxycycline on progression of osteoarthritis: results of a randomized, placebo-controled, double-blind trial. Arthritis Rheum 2005; 52:2015-25.

41. Felson DT. The sources of pain in knee osteoarthritis. Curr Opin Rheumatol 2005; 17:624-28.

42. Grubb BD. Activation of sensory neurons in the arthritic joint. Novartis Found Symp 2004; 260:28-36.

43. Woolf CJ, Salter MW. Neuronal plasticity: increasing the gain in pain. Science 2000; 288:1765-9.

44. Kraychette DC, Calasans MTA, Valente CML. Citocinas próinflamatórias e dor. Rev Bras Reumatol 2006; 46:199-206.

45. Kidd BL, Urban LA. Mechanisms of inflammatory pain. Br J Anaesth 2001; 87: 3-11. 
46. Kidd BL, Photiou A, Inglis JJ. The role of inflammatory mediators on nociception and pain in arthritis. Novartis Found Symp 2004; 260:122138.

47. Melton L. Osteoarthritis pain goes central. Lancet Neurol 2003; 2:524.

48. Bajaj P, Graven-Nielsen T, Arendt-Nielsen L. Osteoarthritis and its association with muscle hyperalgesia: an experimental, controlled study. Pain 2001; 93:107-114.

49. Bradley LA, Kersh BC, DeBerry JJ, Deutsch G, Alarcón GA, McLain DA. Lessons from fibromyalgia: abnormal pain sensitivity in knee osteoarthritis. Novartis Found Symp 2004; 260:258-76.

50. Orderberg G. Characterization of joint pain in human OA. Novartis Found Symp 2004; 260:105-21.

51. Felson DT, Chaisson CE, Hill CL, Totterman SM, Gale ME, Skinner KM, Kasis L, Gale DR. The association of bone marrow lesions with pain in knee osteoarthritis. Ann Intern Med 2001; 134:541-9.

52. Conaghan PG, Felson DT. Structural associations of osteoarthritis pain: lessons from magnetic resonance imaging. Novartis Found Symp 2004; 260:191-105.

53. Goldring SR, Goldring MB. Biology of the normal joint. In: Harris Jr ED, Budd RC, Genovese MC, Firenstein GS, Sargent JS, Sledge CB, editors. Kelley's Textbook of Rheumatology, $7^{\mathrm{a} e d}$. Philadelphia: WB Saunders Co, 2005.

54. Velosa APP, Teodoro WR, Yoshinari NH. Colágeno na cartilagem osteoartrótica. Rev Bras Reumatol 2003; 45:160-6. 
55. Luo W, Guo C, Zheng J, Chen TL, Wang PY, Vertel BM, et al. Agrecan from start to finish. J Bone Miner Metab 2000; 18:51-6.

56. Volpi N. Advances in chondrotin sulfate analysis: application in physiological and pathological states of connective tissue and during pharmacological treatment of osteoarthritis. Curr Pharm Des 2006; 12:639-58.

57. Varki A, Cummings R, Esko J, Freeze H, Hart G, Marth J, editores. Essentials of Glycobiology. $1^{\mathrm{a} e d .}$ New York: Cold Spring Harbor Laboratory Press; 1999.

58. Kuettner KE, Thonar EJMA. Cartilage integrity and homeostasis. In: Klipper JH, Dieppe PA, editors. Rheumatology, $2^{\mathrm{a}}$ ed. London : Mosby, 1997.

59. Wang L, Almqvist KF, Broddlez C, Veys EM, Verbrugen G. Evaluation of chondrocyte cell-associated matrix by flow citometry. Osteoarthritis Cartilage 2001; 9:454-62.

60. Pritzker KP, Gay S, Jimenez SA, Ostergaard K, Pelletier JP, Revell PA, Salter d, van den Berg WB. Osteoarthritis cartilage histopathology: grading and staging. Osteoarthritis Cartilage 2006; 14(1):13-29.

61. Mort JS, Billington C. Articular cartilage and changes in arthritis: matrix degradation. Arthritis Res 2001; 3:337-41.

62. Aigner T, Mckenna L. Molecular pathology and pathobiology of osteoarthritic cartilage. Cell Moll Life Sci 2002; 59:5-18. 
63. Mankin HJ, Lipiello L. The glycosaminoglycans of normal and arthritic cartilage. J Clin Invest 1971; 50:1712-19.

64. Ishiguro $\mathrm{N}$, Ito $\mathrm{T}$, Ito $\mathrm{H}$, Iwata $\mathrm{H}$, Jugessur $\mathrm{H}$, Ionescu $\mathrm{M}$, et al. Relationship of matrix metalloproteinases and their inhibitors to cartilage proteoglycan and collagen turnover:analyses of synovial fluids from patients with osteoarthritis. Arthritis Rheum 1999;42:12936.

65. Verbruggen G. Chondroprotective drugs in degenerative joint diseases. Rheumatology 2006; 45:129-38.

66. Abadie E, Ethgen D, Avouac B, Bouvenout G, Brancol J, Bruyere O, et al. Recommendations for the use of new methods to assess the eficacy of disease-modifying drugs in the treatment of osteoarthritis. Osteoarthritis Cartilage 2004; 12: 263-8.

67. Altman RD, Abadie E, Avouac B, Bouvenot G, Branco J, Bruyere O, et al. Total joint replacement of hip or knee as an outcome measure for structure modifying trials in osteoarthritis. Osteoarthritis Cartilage $2005 ; 13: 13-9$.

68. Altman RD, Hochberg MC,Moskowitz RW, Schnitzer TJ, American College of Rheumatology Subcommittee on Osteoarthritis Guidelines. Recommendations for the medical management of osteoarthritis of the hip and knee: 2000 update. Arthritis Rheum 2000;43:1905-15.

69. Jordan KM, Arden NK, Doherty M, Bannwarth B, Bijlsma JW, Dieppe P, et al. Standing Committee for International Clinical Studies Including Therapeutic Trials ESCISIT. EULAR recommendations 
2003: an evidence based approach to the management of knee osteoarthritis: report of a Task Force of the Standing Committee for International Clinical Studies Including Therapeutic Trials (ESCISIT). Ann Rheum Dis 2003; 62:1145-55.

70. Buckland-Wright C. Workshop for consensus in OA imaging. Review or the anatomical and radiological differences between fluoroscopic and non-fluoroscopic positioning of osteoarthritis knees. Osteoarthritis Cartilage 2006; 14: A19-31.

71. Rovati LC, Pavelka K, Giacovelli G, Reginster JY. Assessment of joint space narrowing with conventional standing antero-posterior radiographs: relief in mild-to-moderate pain is not a confounder in recent osteoarthritis structure-modifying drug trials. Osteoarthritis Cartilage 2006; 14: A14-A18.

72. Towheed TE, Maxwell L, Anastassiades TP, Shea B, Houpt J, Robinson V, Hochberb MC, Wells G. Glucosamine therapy for treating osteoarthritis. Cochrane Database Syst Rev 2005;(2):CD002946.

73. McAlindon TE, LaValley MP, Gulin JP, Felson DT. Glucosamine and chondroitin for treatment of osteoarthritis: a systematic quality assessment and meta-analysis. JAMA 2000;283:1469-75.

74. Richy F, Bruyere O, Ethgen O, Cucherat M, Henrotin Y, Reginster JY. Structural and symptomatic efficacy of glucosamine and chondroitin in knee osteoarthritis: a comprehensive meta-analysis. Arch Intern Med 2003; 163:1514-22. 
75. Leeb BF, Schwietzer H, Montag K, Smolen JS. A metaanalysis of chondroitin sulphate in the treatment of osteoarthritis. $J$ Rheumatol 2000;27:205-11.

76. Clegg DO, Reda DJ, Harris C, Klein MA, O’Dell JR, Hooper MM, et al. Glucosamine, chondroitin sulfate, and the two in combination for painful knee osteoarthritis. N Engl J Med 2006;354(8):795-808.

77. Altman RD, Abramson S, Bruyere O, Clegg D, Herrero-Beamount G, Maheu E, Moskowitz R, Pavelka K, Reginster JY. Commentary: osteoarthritis of the knee and glucosamine. Osteoarthritis Cartilage 2006; 14:963-6.

78. Herrero-Beaumont G, Roman JA, Trabado MC,Blanco FJ, Benito P, Martin-Mola E, et al. Effects of glucosamine sulfate on 6-month control of knee osteoarthritis symptoms vs placebo and acetaminophen: results from the Glucosamine Unum in Die Efficacy (GUIDE) trial. Arthritis Rheum 2005; 52:S460.

79. Biggee BA, Blinn CM, McAlindon TE, Nuite M, Silbert JE. Low levels of human serum glucosamine after ingestion of glucosamine relative to capability for peripheral effectiveness. Ann Rheum Dis 2006; 65:222-6.

80. Persiani S, Roda E, Rovati LC, Locatelli M. Glucosamine oral bioavailability and plasma pharmacokinetics after increasing doses of crystalline glucosamine sulfate in man. Osteoarthritis Cartilage 2005; 13:1041-49. 
81. Verges J, Castaneda-Hernandez G. On the bioavailability of chondroitin sulfate formulations: proposed criteria for bioequivalence studies. Proc West Pharmacol Soc 2004;47:50-3.

82. McAlindon T. Why are clinical trials of glucosamine no longer uniformly positive? Rheum Dis Clin N Am 2003; 29: 789-801.

83. Alvarez-Soria MA, Largo R, Calvo E, Egido J, Herrer-Beaumont G. Differential anticatabolic profile of glucosamine sulfate versus other anti-osteoarthritic drugs on human osteoarthritic chondrocytes and sinovial fibroblasts in culture. Osteoarthritis Cartilage 2005; 13:S153.

84. Chan PS, Caron JP, Rosa GJ, Orth MW. Glucosamine and chondroitin sulfate regulate gene expression and synthesis of nitric oxide and prostaglandin E (2) in articular cartilage explants. Osteoarthritis Cartilage 2005; 13(5):387-94.

85. Largo R, Alvarez-Soria MA, Diez-Ortego J, Calvo E, Sanchez-Pernaute O, Egido J, et al. Glucosamine inhibits IL-1 beta-induced NFkappaB activation in human osteoarthritic chondrocytes. Osteoarthritis Cartilage 2003; 11:290-8.

86. Tiraloche G, Girard C, Chouinard L, Sampalis J, Moquin L, Ionescu M, Reiner A, Poole AR, Laverty S. Effect of oral glucosamine on cartilage degradation in a rabbit model of osteoarthritis. Arthritis Rheum 2005;52(4):1118-28.

87. Lippiello L, Woodward J, Karpman R, Hammad TA. In vivo chondroprotection and metabolic synergy of glucosamine and chondroitin sulfate. Clin Orthop 2000; 381:229-40. 
88. Ameye LG, Young MF. Animal models of osteoarthritis: lessons learned while seeking the 'Holy Grail'. Curr Opin Rheumatol 2006; 18:537-47.

89. Williams JM, Felten DL, Peterson RG, O'Connor BL. Effects of surgically induced instability on rat knee articular cartilage. J Anat 1982;134:103-9.

90. Stoop R, Buma P, van der Kraan PM, Hollander AP, Billinghurst RC, Poole AL, et al. Differences in type II collagen degradation between peripheral and central cartilage of rat stifle joints after cranial cruciate ligament transection. Arthritis Rheum 2000; 43:2121-31.

91. Hayami T, Pickarski M, Zhuo Y, Wesolowski GA, Rodan GA, Duong LT. Characterization of articular cartilage and subchondral bone changes in the rat anterior cruciate ligament transection and meniscectomized models of osteoarthritis. Bone 2006; 38:234-43.

92. Hayami T, Pickarski M, Wesolowski GA, Mclane J, Bone A, Destefano J, et al. The Role of Subchondral Bone Remodeling in Osteoarthritis: Reduction of Cartilage Degeneration and Prevention of Osteophyte Formation by Alendronate in the Rat Anterior Cruciate Ligament Transection Model. Arthritis Rheum 2004; 50:1193-1206.

93. Galois L, Etienne S, Grossin L, Watrin-Pinzano A, Coumil-Henrionnet C, Loeuille D. Dose-response relationship for exercise on severity of experimental osteoarthritis in rats: a pilot study. Osteoarthritis Cartilage 2004; 12: 779-86. 
94. Dietrich $\mathrm{CP}$, Dietrich SMC. Electrophoresis behavior of acidic mucopolysaccharides in diamine buffers. Annal Biochem 1976; 70:645-7.

95. Kobayashi K, Imaizumi R, Sumichika H, Tanaka H, Goda M, Fukunari A, et al. Sodium iodoacetate-induced experimental osteoarthritis and associated pain model in rats. $J$ Vet Med Sci 2003; 65:1195-99.

96. Fernihough J, Gentry C, Malcangio M, Fox A, Rediske J, Pellas T, et al. Pain related behaviour in two models of osteoarthritis in the rat knee. Pain 2004; 112:83-93.

97. Combe R, Bramwell S, Field MJ. The monosodium iodacetate model of osteoarthritis: a model of chronic nociceptive pain in rats? Neuroscience Letters 2004; 370:236-240.

98. Pomonis JD, Boulet JM, Gottshall SL, Philips S, Sellers R, Bunton T, et al. Development and pharmacological characterization of a rat model of osteoarthritis pain. Pain 2005; 114: 339-46.

99. Bove SE, Laemont KD, Brooker RM, Osborn MN, Sanchez BM, Guzman RE, et al. Surgically induced osteoarthritis in the rat results in the development of both osteoarthritis-like joint pain and secondary hiperalgesia. Osteoarthritis Cartilage 2006; 14: 1041-8.

100. Vilensky JA, O'Çonnor BL, Brandt K, Dunn EA, Rogers PI. Serial kinematic analysis of the trunk and limb joints after anterior cruciate ligament transaction: Temporal, spatical, and angular changes in a canine model of osteoarthritis. J Electromyogr Kinesiol 1994;4:181-92. 
101. Herzog W, Adams ME, Matyas JR, Brooks JG. Hindlimb loading, morphology and biochemistry of articular cartilage in the ACL-deficient cat knee. Osteoarthritis Cartilage 1993; 1: 243-51.

102. Suter E, Herzog W, Leonard TR, Nguyen H. One-year changes in hind limb kinematics, ground reaction forces and knee stability in an experimental model of osteoarthritis. J Biomechanics 1998; 31:511-517.

103. Tallarida RJ, Cowan A, Raffa RB. Antinociceptive synergy, additivity and subadditivity with combinations of oral glucosamine plus nonopioid analgesics in mice. J Pharmacol Exp Ther 2003; 307: 699-704.

104. Cohen M, Wolfe R, Mai T, Lewis D. A randomized, double-blind, placebo controlled trial of a topical cream containing glucosamine sulfate, chondroitin sulfate, and camphor for osteoarthritis of the knee. $J$ Rheumatol 2003; 30:523-28.

105. Rocha JCS, Peixoto ME, Jancar S, Cunha FQ, Ribeiro RA,Rocha FA. Dual effect of nitric oxide in articular inflammatory pain in zymosan induced arthritis in rats. Br J Pharmacol 2002; 136:588-96.

106. Lawand NB, Wilis WD, Westlund KN. Blockage of joint inflammation and secondary hyperalgesia by L-NAME, a nitric oxide synthase inhibitor. Neuroreport 1997; 8: 895-9.

107. Durate ID, Lorenzetti BB, Ferreira SH. Peripheral analgesia and activation of the nitric oxide-cyclic GMP pathway. Eur $J$ Pharmacol 1990; 186:289-93.

108. Sousa AM, Prado WA. The dual effect of a nitric oxide donor in nociception. Brain Res 2001; 897(1-2):9-19. 
109. Neil KM, Orth MW, Coussens PM, Chan PS, Caron JP. Effects of glucosamine and chondroitin sulfate on mediators of osteoarthritis in cultured equine chondrocytes stimulated by use of recombinant equine interleukin-1beta. Am J Vet Res 2005; 66:1861-69.

110. Shikhman AR, Kuhn K, Alaaeddine N, Lotz M. N-acetylglucosamine prevents IL-1 beta-mediated activation of human chondrocytes. $J$ Immunol 2001; 166: 5155-60.

111. Meiningeer CJ, Kelly KA, Li H, Haynes TE, Wu G. Glucosamine inhibits inducible nitric oxide synthesis. Biochem Biophys Res Commun 2000; 279:234-9.

112. Hua J, Suguro S, Hirano S, Sakamoto K, Nagaoka I. Preventive actions of a high dose glucosamine on adjuvant arthritis in rats. Inflamm Res $2005 ; 54: 127-32$.

113. Mankin HJ, Dorfman H, Lippiello L, Zarins A. Biochemical and metabolic abnormalities in articular cartilage from osteoarthritic human hips. II. Correlation of morphology with biochemical and metabolic data. $J$ Bone Joint Surg 1971; 53A: 523-37.

114. Ostergaard K, Petersen J, Andersen CB, Bendtzen K, Salter DM. Histologic/histochemical grading system for osteoarthritic articular cartilage. Reproducibility and validity. Arthritis Rheum 1997; 40:1766-71.

115. Ostergaard K, Andersen CB, Petersen J, Bendtzen K, Salter DM. Validity of histopathological grading of articular cartilage from osteoarthritic knee joints. Ann Rhem Dis 1999; 58:208-13. 
116. Oegema TR Jr, Deloria LB, Sandy JD, Hart DA. Effect of oral glucosamine on cartilage and meniscus in normal and chymopapaininjected knees of Young rabbits. Arthritis Rheum 2002; 46:2495-503.

117. Mankin HJ, Brandt KD. Pathogenesis of osteoarthritis. In Ruddy S, Harris, ED Jr, Sledge CB (eds): Kelley's Textbook of Rheumatology, 6th ed. Philadelphia ,W.B. Saunders Company, 2001, p 1391.

118. Vignon E, Arlot M, Harmann D, Moyen B, Ville G. Hypertrophic repair of articular cartilage in experimental osteoarthrosis. Ann Rheum Dis 1983; $42: 82-8$

119. Brandt K, Braunstein EM, Visco DM, O'Connor B, Heck D, Albrecht M. Anterior (cranial) cruciate ligament transection in the dog: a bona fide model of osteoarthritis, not merely of cartilage injury and repair. $J$ Rheumatol 1991; 18:436-46.

120. Brown MP, Trumble TN, Merritt KA. A simplified method for determining synovial fluid chondrotin sulfate chain lengh. In: 2006 World Congress on Osteoarthritis, Prague Czech. Osteoarthritis Cartilage 2006; 14 (SupplB):S64 .

121. Bollet AJ, Nance JL. Biochemical Findings in Normal and Osteoarthritic Articular Cartilage. II.Chondroitin Sulfate Concentration and Chain Length, Water, and Ash Content. J Clin Invest. 1966; 45:1170-7.

122. Inerot S, Heinegard D, Audell L, Olsson SE. Articular-cartilage proteoglycans in aging and osteoarthritis. Biochem J. 1978; 169:143-56.

123. Rizkalla G, Reiner A, Bogoch E, Poole AR. Studies of the articular cartilage proteoglycan aggrecan in health and osteoarthritis. Evidence 
for molecular heterogeneity and extensive molecular changes in disease. J Clin Invest. 1992; 90:2268-77. 